\title{
KELEMBAGAAN URUSAN PANGAN DARI MASA KE MASA DAN KEBIJAKAN KETAHANAN PANGAN
}

\author{
Juli Panglima Saragih \\ Pusat Penelitian Badan Keahlian DPR RI \\ Jalan Jenderal Gatot Subroto Senayan Jakarta 10270 \\ Email korespondensi: julipsaragih@gmail.com \\ Naskah Diterima: Juli 2016; Disetujui: Oktober 2016
}

\begin{abstract}
Since independence of Indonesia, authorities and functions of national agency for food affairs often changed until nowadays. This phenomenon can impact on acchieving national food safety. In Presiden Suharto era, agency for food affairs - namely Bulog was successful in stabilizing food price although its statuta as non-profit institution. Meanwhile, politic of foodstock supply in 1998 also more or less give impact on achieving it. Both Law Number 7 Year of 1996 and Law Number 12 Year of 2012 do not clearly regulate about institution on food affairs. Since Bulog became a business company in 2003, Bulog was failure in stabilizing some food prices, except rice. As qualitatif research, this study uses descriptive-analysis as tool to solve problem by analysing historical data relevant with the topic. This study explains that eventhough government has already set up Bulog as single agency for food affairs, but food problems rise up due to multi-dimension problems and complexity of government policies. In this concern, it is needed policy coordination amongst different govt institutions to overcome the increase of food prices. Problems of distribution and marketing also impact on achievement of food safety.
\end{abstract}

Keywords: food safety, national agency for food stock, food product, rice.

JEL Classification: Q11, 13, Q18

Abstrak: Sejak kemerdekaan Indonesia sampai saat ini tugas, kewenangan, dan organisasi kelembagaan urusan pangan selalu berubah-ubah. Perubahan tersebut sedikit banyak berpengaruh terhadap upaya mewujudkan ketahanan pangan nasional. Selama Orde Baru, lembaga pangan Badan Urusan Logistik (Bulog) relatif berhasil dalam menstabilkan harga pangan pokok walaupun Bulog tidak berbentuk badan usaha. Politik pengelolaan pangan juga mempengaruhi pencapaian ketahanan pangan seperti pada masa krisis ekonomi 1998. Pentingnya lembaga pangan juga tidak secara tegas diatur dalam UU No.7 Tahun 1996. Sejak Bulog menjadi badan usaha milik negara berbentuk perusahaan umum tahun 2003, Bulog terus berupaya untuk menstabilkan harga pangan pokok, tetapi masih tidak mampu menurunkan dan menstabilkan harga pangan pokok di luar beras. Studi ini merupakan penelitian kualitatif dengan metode deskriptif-analisis. Data sekunder dari berbagai referensi yang relevan dikumpulkan dan dianalisa guna menjawab permasalahan. Dari hasil analisis antara lain disimpulkan bahwa pemerintah memang sudah menetapkan lembaga urusan pangan seperti Bulog, tetapi masih belum terkoodinasi antar-lembaga padahal urusan pangan bersifat lintas sektor. Salah satu dampaknya adalah masih mahalnya harga sebagian besar komoditas pangan pokok di masyarakat. Mata rantai tata niaga yang cukup panjang, juga menjadi penyebab tidak tercapainya ketahanan pangan nasional.

Kata kunci: ketahanan pangan, Badan Urusan Logistik, komoditas pangan, beras.

Klasifikasi JEL: Q11, 13, Q18 


\section{PENDAHULUAN}

Di tengah himpitan beban ekonomi yang semakin berat terutama sejak Pemerintahan SBY berkuasa 2004, sebagian besar masyarakat di Indonesia masih merasakan mahalnya harga komoditas pangan pokok seperti beras, daging sapi, daging ayam ras, cabai merah, gula pasir, dan kedelai, yang sering terjadi menjelang harihari besar keagamaan. Pada Bulan Ramadhan 2016, misalnya, hanya harga beras yang tidak mengalami lonjakan yang signifikan. Namun anehnya harga sebagian besar pangan pokok seperti daging sapi paska Ramadhan dan Idul Fitri 2016 belum juga turun sesuai dengan kebijakan Presiden Jokowi yaitu di bawah Rp80.000 per Kg. Padahal kebijakan impor daging sapi sudah diberlakukan walaupun relatif terbatas.

Pertanyaannya adalah apakah mahalnya harga pangan pokok seperti daging sapi merupakan permainan mafia pangan atau memang supply yang sangat sedikit di pasar? Gejolak atau permainan harga daging sapi di pasar tersebut telah berdampak pada diberhentikannya Dirjen Peternakan oleh Menteri Pertanian RI. Pertanyaan kemudian adalah bagaimana mengatasi persoalan tersebut agar tidak berulang di kemudian hari? Apakah perlu ada lembaga pemerintah yang seharusnya bertanggung jawab penuh dalam penyediaan pangan pokok seperti daging sapi, cabai merah, beras, atau bahan pangan pokok lainnya yang kenaikan harganya akan berdampak langsung pada kenaikan inflasi di Indonesia? Atau apakah persoalannya bukan pada aspek kelembagaan pangan semata? Pertanyaan di atas mendasari penulisan ini untuk mengidentifikasi dan menganalisa permasalahan pangan dari aspek kelembagaan pangan sejak masa Presiden Sukarno sampai Presiden Jokowi dalam kaitan dengan kebijakan pemerintah mencapai ketahanan pangan nasional.

Pada masa pemerintahan Orde Baru relatif hampir tak terdengar tentang kelangkaan ataupun mahalnya harga sembilan bahan pokok. Karena pada zaman Orde Baru, Badan Urusan Logistik - selanjutnya disebut Bulog merupakan satu-satunya lembaga pemerintah non-departemen (LPND) yang ditugasi sebagai badan penyangga kebutuhan pokok termasuk beras. Tugas pokoknya adalah menstabilisasi harga 7 (tujuh) bahan pokok, antara lain: beras, gula, daging sapi, daging ayam, terigu, telur ayam, dan kedelai. Penugasan Bulog tersebut tertuang dalam Keppres RI Nomor 50 Tahun 1995. Hasilnya terbukti efektivitas pengendalian harga produsen dan stabilitas harga di konsumen hingga 1998 sangat baik dan terjaga, sebelum krisis moneter terjadi Mei 1998. Masyarakat merasa tenang dengan stabilnya harga kebutuhan pokok di pasar.

Keberhasilan Bulog di era Orde Baru tersebut juga tidak lepas dari tata kelola dan manajemen institusi Bulog. Pada masa Orde Baru Bulog-walaupun secara garis koordinasi di bawah Kementerian Sekretariat Negara, tetapi tugas dan tanggungjawabnya langsung kepada Presiden. Hal ini mendorong program swasembada beras sempat terwujud pada masa Presiden Suharto tahun 1980-an karena perhatian langsung dari Presiden terhadap Bulog. Setelah krisis moneter 1998 berlalu, bagaimana peran Bulog? Mengapa Bulog terkesan tidak mampu menguasai pasar sebagian besar komoditas pangan pokok saat ini? Pertanyaan tersebut belum terjawab tuntas hingga saat ini.

Peran Bulog diakui telah bergeser pada saat setelah terjadi krisis moneter tahun 1998. Perubahan peran dan wewenang Bulog sejalan dengan perubahan politik sebagian besar BUMN yang merupakan implikasi politik dari kesepakatan perjanjian Letter of Intent (LoI) antara pemerintah Indonesia dengan International Monetary Fund (IMF). Di samping itu juga sebagai implikasi dari lahirnya UU No.19 Tahun 2003 tentang BUMN.

Artinya, Bulog yang semula berperan sebagai badan penyangga pangan pokok dengan penitikberatan stabilisasi harga pangan, 
berubah menjadi hampir semuanya bertujuan pada orientasi profit semata walaupun Bulog sudah merupakan badan usaha milik negara berbentuk perusahaan umum (perum). Padahal walaupun BUMN berbentuk perusahaan umum tidak hanya mengejar keuntungan saja, tetapi juga sebagai agent of development dalam menyediakan barang publik yang dibutuhkan masyarakat banyak, seperti beras. Unsur agen pembangunan dan agen perubahan sebagai "intervensi" pemerintah secara langsung dalam menyeimbangkan dan menstabilkan harga pangan di pasar dalam kasus Bulog, menjadi sirna atau hilang. Peran Bulog tak ubahnya dengan perusahaan lain yang penekanan utamanya pada botom line atau keuntungan yang menjadi indikator keberhasilan kinerja usaha.

Jika masyarakat pernah mengalami stabilitas harga dan tersedianya bahan pokok karena peran Bulog pada masa Orde Baru, mengapa pemerintah tidak mengembalikan peran Bulog seperti semula, yang tentu dengan penyempurnaan atau revitalisasi tugas dan fungsinya. Penguatan peran dan fungsi Bulog diprediksi akan mampu menjaga stabilitas harga pangan dan menjaga minat petani untuk tetap menanam padi dan berbagai komoditas pangan lain.

Indonesia perlu belajar dari Thailand dalam pengelolaan beras. Semua beras yang diproduksi petani di Thailand dibeli Pemerintah dengan harga yang memungkinkan petani meraih keuntungan, kemudian disalurkan kepada rakyat dengan harga yang terjangkau oleh daya beli masyarakat Thailand. Mengembalikan fungsi Bulog sebagai penyangga berarti memberi keleluasaan untuk membeli seluruh hasil produksi pangan petani dan menyalurkannya ke daerah yang bukan sentra produksi beras seperti Indonesia Bagian Timur dan daerah kepulauan lainnya. Hal ini juga dapat diterapkan misalnya untuk komoditas lain. Dengan demikian Bulog diharapkan mampu memenuhi semua unsur, baik produsen maupun konsumen. Bulog perlu menetapkan harga pembelian pemerintah (HPP) sebagai upaya memberi insentif kepada petani dalam meningkatkan produksi pangan, khususnya beras.

Adapun upaya untuk melindungi konsumen terutama yang berpenghasilan rendah dan masyarakat miskin, maka perlu ditetapkan harga maksimum beberapa komoditas pangan pokok seperti beras. Pemerintah dinilai perlu memberi keleluasaan kepada Bulog untuk membeli semua beras yang dihasilkan petani dengan beragam kualitas dan harga. Untuk itu harus ada patokan dalam membeli gabah pada tingkat harga dan kualitas tertentu. Hal ini disebut dengan harga pembelian pemerintah (HP).

Hasil pembelian beras oleh Bulog dengan harga ditetapkan pemerintah, maka dapat digunakan pemerintah untuk berbagai keperluan khususnya untuk menyejahterakan rakyat dengan harga beras terjangkau. Selain itu agar turbulensi harga pangan di pasar dunia tidak langsung berimbas pada harga pangan domestik, perlu diupayakan relasi harga terhadap pasar dunia dengan fluktuasi yang lebar.

Bulog juga seharusnya memiliki stok penyangga dalam jumlah yang cukup. Karena tanpa stok penyangga dalam jumlah yang cukup, mustahil pemerintah dapat mengintervensi pasar untuk stabilisasi harga saat terjadi gejolak harga pangan di pasar. Melalui stabilisasi harga pangan yang langsung di bawah Presiden, Bulog seharusnya mampu mengelola pangan dengan manajemen yang lebih modern dengan tetap memegang teguh prinsip tata kelola good governance.

Komisi Pengawas Persaingan Usaha (KPPU) menilai, peranan Bulog dalam menjaga stabilitas harga beras masih sangat dibutuhkan. Sayangnya, Bulog saat ini dinilai tak memiliki kekuatan layaknya masa Orde Baru dulu. Bulog sekarang tidak punya power untuk melakukan stabilisasi harga dan meningkatkan stok beberapa komoditas pangan pokok, karena Bulog dituntut sebagai perusahaan (entitas 
bisnis), dan statusnya bukan sebagai lembaga penyangga pangan tetapi pelaku pasar biasa.

Persoalan ketahanan pangan merupakan masalah yang komprehensif yang mesti dilihat dari sisi multidimensi. Salah satunya adalah masalah kelembagaan yang mengurusi pangan seperti Bulog. Kelembagaan pangan sudah dibentuk pemerintah sejak masa pemerintahan Presiden Soekarno sampai saat ini. Tetapi persoalan pangan seperti lonjakan harga komoditas pangan pokok, belum juga berkurang dan belum terselesaikan. Masih sulitnya upaya untuk menstabilkan harga pangan pokok di masyarakat, salah satu penyebabnya adalah masalah kelembagaan Bulog yang di sisi hilir yang perlu direformasi, direvitalisasi, dan diberikan tugas dan kewenangan lebih untuk menjaga ketahanan pangan. Bulog hanya mampu menjaga stabilitas harga beras dengan strategi peningkatan stok beras, tetapi belum mampu menstabilkan harga pangan pokok lainnya.

\section{METODE PENELITIAN}

Penelitian ini merupakan peneltian kualitatif dengan metode deskriptif analisis. Metode ini mencoba mengggambarkan dan mengidentifikasi permasalahan dalam tulisan ini serta menganalisisnya berdasarkan data dan informasi yang relevan terhadap topik tulisan. Teknik analisis data adalah dengan menggunakan konsep atau kerangka berpikir sebagai alat analisa yakni konsep ketahanan pangan dalam kaitan status, tugas, wewenang kelembagaan urusan pangan selama ini. Data yang dianalisis merupakan data sekunder melalui studi kepustakaan.

Sedangkan tujuan dari penelitian kualitatif ini antara lain adalah untuk mengkaji dan menjawab permasalahan ketahanan pangan dikaitkan dengan perkembangan kelembagaan pangan sejak masa pemerintahan Presiden Soekarno sampai pemerintahan Presiden Jokowi.

\section{HASIL DAN PEMBAHASAN}

\section{Masa Presiden Soekarno Sampai Presiden Jokowi}

Lembaga urusan pangan sebenarnya sudah dibentuk pemerintah sejak lama. Tiga tahun setelah Indonesia merdeka, Presiden Soekarno membentuk Panitia Agraria Jogyakarta pada 21 Mei 1948 yang bertanggungjawab menangani kebijakan pangan. Kemudian Panitia ini membentuk Jawatan Pengawasan Makanan Rakyat dan Yayasan Bahan Makakan (BAMA) yang kewenangannya antara lain; membeli, menjual, dan mengadakan persediaan pangan. Ketiga lembaga tersebut kemudian diganti dengan Yayasan Urusan Bahan Makanan (YUBM), dan Yayasan Badan Pembelian Padi (YBP2). Pada periode 1952-1956, pemerintahan Soekarno menerapkan kebijakan swasembada beras melalui Program Kesejahteraan Kasimo dengan mendirikan YUBM tersebut pada 19531956. Kemudian tahun 1967, kedua yayasan di atas dilebur dan diganti menjadi Badan Urusan Logistik (Bulog) sebagai badan pembeli tunggal, (Eko Suksmantri, dkk;2012;2). Pada periode inilah merupakan awal pembentukan Bulog sebagai lembaga urusan pangan secara langsung.

Kemudian periode 1956-1964, program swasembada beras tetap dijalankan melalui program Sentra Padi yang diatur Yayasan Badan Pembelian Padi (YBPP). Pada tahun 1963, Presiden Soekarno memasukkan komoditas jagung sebagai bahan pangan pengganti beras karena langkanya beras di pasar sejak 1963. Pada tahun 1964, pemerintah Soekarno menerapkan kebijakan Panca Usaha Tani dan sentra padi, yakni: 1) penggunaan bibit unggul; 2) pengolahan tanah yang baik; 3) pemilihan pupuk yang lengkap, tepat, dan baik; 4) pengendalian hama dan penyakit tanaman; dan 5) pengairan/irigasi yang baik.

Program sentra padi tersebut akhirnya gagal karena pendanaan yang kurang, masalah logistik, mis-manajemen sistem perkreditan, dan penentuan harga gabah yang lemah. 
Kemudian dilanjutkan dengan menerapkan program Demonstrasi Massal-kerja sama antara IPB dengan Departemen Pertanian dan merupakan cikal bakal dari program Bimas pada era Presiden Suharto.

Sementara masa pemerintahan transisi 1965-1967, dibentuk lembaga Komando Logistik Nasional (Kolognas) setelah Presiden Suharto berkuasa, yang kemudian dibubarkan pada 1967. Pada 14 Mei 1967 lahirlah Badan Urusan Logistik (Bulog) sebagai pengganti Kolognasyang berfungsi sebagai agen pembeli beras tunggal seperti disebutkan di atas. Sejak awal berdirinya, Bulog memang difokuskan pada upaya menjaga ketahanan pangan Indonesia melalui dua mekanisme yakni: pertama, stabilisasi harga beras. Kedua, pengadaan beras bulanan untuk PNS dan TNI/Polri. Melihat fakta di atas, sebenarnya perhatian pemerintah terhadap masalah pangan sudah ada sejak awal kemerdekaan. Namun terjadinya pergantian rezim pemerintahan menyebankan kelembagaan yang mengurusi pangan juga berubah-bah sehingga upaya mewujudkan swasembada pangan tidak berhasil pada era Presiden Soekarno.

YUBM, YBPP, dan Dewan Bahan Makanan kemudian dilebur menjadi Badan Pelaksana Urusan Pangan (BPUP). Namun lembaga ini kembali gagal mengurusi pangan antara lain karena banyak gudang BPUP kosong akibat kesulitan dana untuk membeli hasil produksi dalam negeri dan impor. Dalam masa pemerintahan Presiden Soekarno, politik pangan adalah pembangunan pertanian sebagai urusan hidup-mati bangsa. Tetapi sebagian besar imlementasinya gagal, tidak hanya disebabkan oleh kegagalan produksi beras tetapi ketiadaan anggaran negara untuk menambah stok beras sehingga mengakibatkan harga beras meningkat tajam mulai tahun 19641965. Kegagalan swasembada pangan pada pemerintahan Presiden Soekarno menyebabkan tidak tercapainya kebijakan ketahanan pangan yang dibuktikan dengan meningkatnya harga beras sejak 1964-1967. Sejarah mencatat 31 Mei
1967 merupakan momen berdirinya Badan Urusan Logistik.

Digantinya Kolognas dengan Bulog tahun 1967 oleh Presiden Suharto, berdasarkan Keppres Nomor 114/KEP/1967, Bulog kemudian diberi tugas dan fungsi sebagai satusatunya badan pembelian tunggal (Single Purchasing Agency) melalui penerbitan Keppres Nomor 272 Tahun 1967. Status hukum Bulog adalah lembaga pemerintah non-departemen (LPND). Kemudian pada Januari 1969 melalui Keppres Nomor 11 Tahun 1969, Bulog direorganisasi dan direstrukturisasi dengan tugas membantu pemerintah menstabilkan harga pangan khususnya (sembilan) 9 bahan pangan pokok atau sembako, (lihat Tabel $1 \mathrm{di}$ bawah). Artinya sejak 1969-1997 dengan dilakukannya reorganisasi dan perombakan struktur (restrukturisasi), tugas dan kewenangan Bulog semakin bertambah dengan diberi kewenangan mengurusi komoditas pangan lainnya seperti gula pasir dan tepung terigu (1971), daging sapi (1974), kedelai (1977), jagung (1978), kacang tanah dan kacang hijau (1978). Masa pemerintahan Presiden Suharto merupakan momen penting di sektor pangan di tanah air yakni dengan lahirnya UU No. 7 Tahun 1996 tentang Pangan (Lembaran Negara Republik Indonesia Tahun 1996 Nomor 90, Tambahan Lembaran Negara Nomor 3650). UU Pangan ini lahir antar lain didorong oleh lahirnya Keppres Nomor 50 Tahun 1995 tentang Badan Urusan Logistik (lihat Tabel 1).

Tetapi pembentukan Bulog 1967 tidak serta-merta masalah pangan teratasi. Indonesia pernah mengalami kekuarangan beras periode 1969-1982 dan yang paling parah tahun 1972. Meskipun Bulog melakukan langkah stabilisasi pasokan dan harga beras, Bulog tidak siaga. Bulog membutuhkan waktu 1 tahun untuk membangun kembali cadangan beras strategisnya. Harga beras tahun 1972 meningkat lebih dari 100\% (Radius Prawiro; 2004:170).

Sepanjang 1970-an sampai 1980-an dilakukan investasi besar-besaran untuk membangun infrastruktur pertanian seperti 
waduk, bendungan, dan irigasi. Pada Rencana Pembangunan Lima Tahun (Repelita I-III), swasembada pangan merupakan fokus tersendiri yang dibuat Pak Harto. Di dalam Pelita I, pembangunan pertanian dan irigasi bertujuan untuk peningkatan produksi pangan terutama beras. Pada masa pemerintahan Pak Harto juga dikembangkan institusi-institusi yang mendukung pertanian, mulai dari koperasi yang melayani kebutuhan pokok petani dalam usaha agribisnisnya, Bulog yang menampung hasil dari petani, institusi penelitian seperti BPTP yang berkembang untuk menghasilkan inovasi untuk pengembangan pertanian. Pada masa Pak Harto salah satu produknya yang cukup terkenal adalah Varietas Unggul Tahan Wereng (VUTW), hingga berbagai bentuk kerjasama antar lembaga yang terkait penyediaan sarana prasaran yang mendukung pertanian seperti irigasi dan pembangunan pabrik pupuk.

Strategi kebijakan pangan Suharto masa Orde Baru antara lain penyediaan sarana penunjang, seperti pupuk, diamankan dengan membangun pabrik-pabrik pupuk. Para petani dimodali dengan kemudahan memperoleh kredit bank. Pemasaran hasil panen mereka dijamin dengan kebijakan harga dasar dan pengadaan pangan. Pemeirntah juga memperkenalkan manajemen usaha tani, dimulai dari Panca Usaha Tani, Bimas, Operasi Khusus, dan Intensifikasi Khusus yang terbukti mampu meningkatkan produksi pangan, terutama beras. Saat itu, budi daya padi di Indonesia adalah yang terbaik di Asia. Pemerintah memfasilitasi ketersediaan benih unggul, pupuk, pestisida melalui subsidi yang terkontrol dengan baik. Pabrik pupuk dibangun seperti Pabrik Pupuk Sriwijaya di Palembang, dan Asean Aceh Fertilizer di Aceh. Program kerja sektor pertanian masa Presiden Suharto berbuah prestasi. Indonesia yang dikenal sebagai negara agraria pengimpor beras terbesar pada 1966, telah mampu mencukupi kebutuhan pangan dalam negeri melalui swasembada beras pada 1984. Jika 1969,
Indonesia baru memproduksi beras sekitar 12,2 juta ton beras, namun pada 1984 mencapai 25,8 juta ton beras (naik 111,47\% dalam 15 tahun). Kesuksesan ini mengantarkan Presiden Suharto berpidato di depan Konferensi ke-23 FAO di Roma, Italia, 14 November 1985.

Dengan ditandatanganinya Letter of Intents antara pemerintah Indonesia dengan IMF, pemerintah mengeluarkan Keppres Nomor 19 Tahun 1998 yang menggantikan 2 keppres yakni Keppres Nomor 50 Tahun 1995 dan Keppres Nomor 45 Tahun 1997. Namun sayangnya dalam Keppres Nomor 50 Tahun 1995, Bulog justru sangat berperan dalam mengurusi 9 komoditas pangan pokok termasuk menstabilkan harganya, khususnya beras. Bulog memiliki posisi strategis dalam mengurusi pangan pokok di Indonesia. Sejak bertahun-tahun sejak swasembada beras 1984/1985, masyarakat tidak pernah merasakan lonjakan-lonjakan harga beras dan harga pangan lainnya. Selama kurang lebih 28 tahun (1969-1997), masyarakat Indonesia menikmati harga pangan pokok yang relatif stabil. Fungsi kelembagaan Bulog pada periode tersebut memang kuat dan diberi tugas dan kewenangan penuh untuk urusan pangan pokok (lihat Tabel 2).

Baik Keppres No.45 Tahun 1997 maupun Keppres No.19 Tahun 1998 merupakan dua keppres yang mengurangi secara drastis tugas, fungsi, dan kewenangan Bulog dalam urusan pangan. Bulog diberi wewenang hanya menangani komoditas beras dan gula. Sejak 1998 komoditas di luar beras dan gula pasir diserahkan kepada mekanisme pasar sehingga menyebakan lonjakan harga komoditas pangan lain sangat tinggi yang berdampak pada inflasi yang tinggi (inflatoir) tahun 1998-1999.

Fakta di atas juga disebabkan adanya liberalisasi pasar pangan yang dihembuskan dalam perjanjian Agreement on Agriculture oleh World Trade Organisation (WTO)-Indonesia telah meratifikasinya tahun 1995 lewat penghapusan subsidi dan pencabutan hak monopoli negara dalam struktur pasar pangan. 
Hal ini memperlemah akses masyarakat terhadap pangan, memunculkan para pencari rente baru, dan menaikkan harga komoditi pangan. Dalam jangka panjang, pasar akan dikendalikan pemilik modal kuat, sehingga produksi pangan akan berorientasi bukan pada komoditi yang dibutuhkan rakyat banyak, melainkan pada komoditas yang berdaya jual tinggi. Padahal, pangsa pengeluaran pangan terhadap total pengeluaran rumah tangga di Indonesia tergolong amat tinggi, yaitu antara $67.2 \%$, dengan $52.3 \%$ di pedesaan dan perkotaan. Ketika Bulog berubah menjadi perum, maka tidak ada lagi hak Bulog untuk mempengaruhi arah dan besaran impor ataupun ekspor. Bulog pun kehilangan hak eksklusifnya menjadi badan pengendali harga pangan. Padahal jelas tidak dapat dipungkiri bahwa masalah pangan dan stabilitas harga merupakan persoalan strategis bagi semua negara, termasuk Indonesia. Hal ini merupakan skenario AoA WTO yang mengharuskan pemerintah Indonesia membuat beberapa kebijakan yang mencabut peran sentral Bulog, baik sebagai pelaku, distributor maupun pengawas tunggal di sektor pangan yang sangat membahayakan kondisi pangan Indonesia.

\section{Tabel 1. Kelembagaan Urusan Pangan di Indonesia}

Sejak Pemerintahan Presiden Soekarno Sampai Presiden Jokowi

\begin{tabular}{|c|c|c|c|}
\hline $\begin{array}{l}\text { Kelembagaan Urusan } \\
\text { Pangan }\end{array}$ & Tugas dan Wewenang & $\begin{array}{l}\text { Dasar Hukum } \\
\text { Penetapan }\end{array}$ & $\begin{array}{l}\text { Pemerintahan/ } \\
\text { Tahun } \\
\text { Ditetapkan }\end{array}$ \\
\hline $\begin{array}{l}\text { Jawatan Pengawasan } \\
\text { Makanan Rakyat }\end{array}$ & $\begin{array}{l}\text { Tugas pokok: membeli, menjual, dan } \\
\text { mengadakan persediaan pangan. }\end{array}$ & - & $\begin{array}{l}\text { Presiden Soekarno } \\
\text { (1948) }\end{array}$ \\
\hline $\begin{array}{ll}\text { Yayasan } & \text { Bahan } \\
\text { Makanan } & \\
\end{array}$ & $\begin{array}{l}\text { Tugas pokok: membeli, menjual, dan } \\
\text { mengadakan persediaan pangan }\end{array}$ & - & $\begin{array}{l}\text { Presiden Soekarno } \\
(1948-1952)\end{array}$ \\
\hline $\begin{array}{l}\text { Yayasan Urusan } \\
\text { Bahan Makanan }\end{array}$ & $\begin{array}{l}\text { Tugas pokok: membeli, menjual, dan } \\
\text { mengadakan persediaan pangan }\end{array}$ & - & $\begin{array}{l}\text { Presiden Soekarno } \\
(1952-1956)\end{array}$ \\
\hline $\begin{array}{l}\text { Yayasan Badan } \\
\text { Pembelian Padi }\end{array}$ & $\begin{array}{l}\text { Tugas pokok: membeli, menjual, dan } \\
\text { mengadakan persediaan pangan }\end{array}$ & - & $\begin{array}{l}\text { Presiden Soekarno } \\
(1952)\end{array}$ \\
\hline $\begin{array}{ll}\text { Dewan } & \text { Bahan } \\
\text { Makanan } & \\
\end{array}$ & - & $\begin{array}{l}\text { PP No.7 Tahun } 1958 . \\
\text { PP No.47 Tahun } 1958 .\end{array}$ & $\begin{array}{l}\text { Presiden Soekarno } \\
\text { (1958) }\end{array}$ \\
\hline \multirow{2}{*}{$\begin{array}{l}\text { Komando } \\
\text { Nasional } \\
\text { (Kolognas) }\end{array}$} & - & - & $\begin{array}{l}\text { Presiden Soekarno } \\
\text { (1965-April 1967) }\end{array}$ \\
\hline & Pembubaran Kolognas & $\begin{array}{l}\text { Keppres No.69 Tahun } \\
1967\end{array}$ & Presiden Suharto \\
\hline $\begin{array}{ll}\text { Badan } & \text { Urusan } \\
\text { Logistik*) } & \end{array}$ & $\begin{array}{l}\text { Tugas pokok: mengamankan penyediaan } \\
\text { pangan dalam rangka menegakkan } \\
\text { eksistensi pemerintahan baru. }\end{array}$ & $\begin{array}{l}\text { Keputusan Presidium } \\
\text { Kabinet } \\
\text { No.114/U/Kep. } \\
\text { /5/1967 }\end{array}$ & $\begin{array}{l}\text { Presiden Suharto } \\
\text { (April 1967) }\end{array}$ \\
\hline Badan Urusan Logistik & $\begin{array}{l}\text { Tugas pokok: menstabilkan dan } \\
\text { mengamankan } 9 \text { bahan pokok. }\end{array}$ & $\begin{array}{l}\text { Keppres No.11 Tahun } \\
1969\end{array}$ & Presidien Suharto \\
\hline Badan Urusan Logistik & $\begin{array}{l}\text { Tugas pokok: melakukan stabilisasi harga } \\
\text { beras. }\end{array}$ & $\begin{array}{l}\text { Keppres No.39 } \text { Tahun } \\
1969 \text { Tgl. } 21 \text { Januari } \\
1969\end{array}$ & $\begin{array}{l}\text { Presiden Suharto } \\
\text { (1969) }\end{array}$ \\
\hline Badan Urusan Logistik & $\begin{array}{l}\text { Tugas pokok: } \frac{2}{2} \text { melaksanakan } \\
\text { pengendalian harga beras, gabah, } \\
\text { gandum dan bahan pokok lainnya guna } \\
\text { menjaga kestabilan harga, baik bagi } \\
\text { produsen maupun konsumen sesuai } \\
\text { dengan kebijaksanaan umum } \\
\text { pemerintah. }\end{array}$ & $\begin{array}{l}\text { Keppres No.39 Tahun } \\
1978\end{array}$ & $\begin{array}{l}\text { Presiden Suharto } \\
\text { (1978) }\end{array}$ \\
\hline
\end{tabular}




\begin{tabular}{|c|c|c|c|}
\hline $\begin{array}{c}\text { Kelembagaan Urusan } \\
\text { Pangan }\end{array}$ & Tugas dan Wewenang & $\begin{array}{l}\text { Dasar Hukum } \\
\text { Penetapan }\end{array}$ & $\begin{array}{l}\text { Pemerintahan/ } \\
\text { Tahun } \\
\text { Ditetapkan }\end{array}$ \\
\hline Badan Urusan Logistik & $\begin{array}{l}\text { Tugas: koordinasi pembangunan pangan } \\
\text { dan meningkatkan mutu gizi pangan. }\end{array}$ & $\begin{array}{l}\text { Keppres No.103 Tahun } \\
1993 .\end{array}$ & $\begin{array}{l}\text { Presiden Suharto } \\
\text { (1993) }\end{array}$ \\
\hline Badan Urusan Logistik & $\begin{array}{l}\text { Tugas pokok: } \\
\text { 1)fokus pada peningkatan stabilisasi dan } \\
\text { pengelolaan persediaan bahan pokok dan } \\
\text { pangan. } \\
\text { 2)mengendalikan harga dan mengelola } \\
\text { persediaan (7 komoditas pangan pokok) } \\
\text { seperti: beras, gula pasir, gandum, terigu, } \\
\text { kedelai, pakan, dan bahan pangan } \\
\text { lainnya, baik secara langsung maupun } \\
\text { tidak langsung, dalam rangka menjaga } \\
\text { kestabilan harga bahan pangan bagi } \\
\text { produsen dan konsumen. } \\
\text { 3)memenuhi kebutuhan } \\
\text { berdasarkan kebijaksanaan umum } \\
\text { pemerintah. } \\
\text { Fungsi Bulog antara lain: } \\
\text { 1)pengadaan dalam negeri; } \\
\text { 2)pengadaan luar negeri; } \\
\text { 3)pengelolaan dan perawatan persediaan; } \\
\text { 2)penganalisasian harga dan pasar, } \\
\text { penyaluran, serta angkutan. }\end{array}$ & $\begin{array}{l}\text { Keppres No. } 50 \text { Tahun } \\
1995 .\end{array}$ & $\begin{array}{l}\text { Presiden Suharto } \\
\text { (1995) }\end{array}$ \\
\hline Badan Urusan Logistik & $\begin{array}{l}\text { Tugas pokok: menangani komoditas } \\
\text { beras dan gula pasir. }\end{array}$ & $\begin{array}{l}\text { Keppres No.45 Tahun } \\
\text { 1997, Tgl.1 Nov } 1997 .\end{array}$ & $\begin{array}{l}\text { Presiden Suharto } \\
\text { (1997) }\end{array}$ \\
\hline Badan Urusan Logistik & $\begin{array}{l}\text { Pemerintah mengembalikan tugas Bulog } \\
\text { seperti Keppres Nomor } 39 \text { Tahun } 1968 \\
\text { yakni menangani komoditas beras saja. }\end{array}$ & 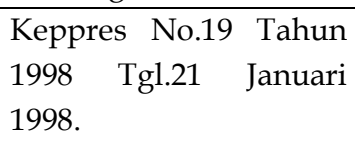 & $\begin{array}{l}\text { Presiden Suharto } \\
\text { (1998) }\end{array}$ \\
\hline Badan Urusan Logistik & $\begin{array}{l}\text { Tugas pokok: melakukan stabilisasi harga } \\
\text { beras. }\end{array}$ & - & $\begin{array}{l}\text { Presiden } \quad \text { BJ. } \\
\text { Habibie } \\
(1998-1999)\end{array}$ \\
\hline Badan Urusan Logistik & 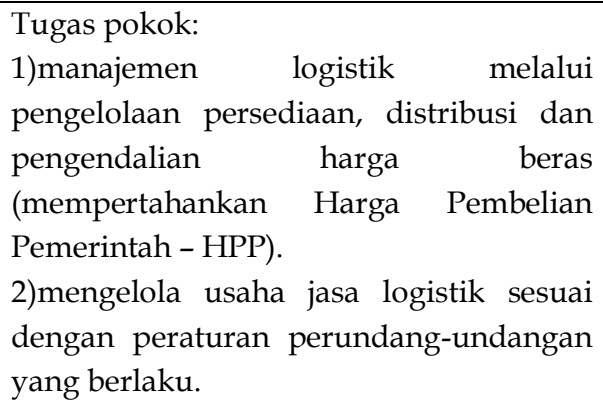 & $\begin{array}{l}\text { Keppres No. } 29 \text { Tahun } \\
2000 .\end{array}$ & $\begin{array}{l}\text { Presiden } \\
\text { Abdulrachman } \\
\text { Wahid } \\
(1999-2001)\end{array}$ \\
\hline Badan Urusan Logistik & $\begin{array}{l}\text { Tugas Pokok: } \\
\text { 1)melaksanakan tugas pemerintahan di } \\
\text { bidang manajemen logistik sesuai dengan } \\
\text { ketentuan peraturan perundang- } \\
\text { undangan yang berlaku; } \\
\text { 2)pengkajian dan penyusunan kebijakan } \\
\text { nasional di bidang manajemen logistik, 3) } \\
\text { pengadaan, pengelolaan persediaan, dan } \\
\text { distribusi beras, serta pengendalian harga } \\
\text { beras; }\end{array}$ & $\begin{array}{l}\text { Keppres No.166 Tahun } \\
2000 .\end{array}$ & $\begin{array}{l}\text { Presiden } \\
\text { Abdurrahman } \\
\text { Wahid } \\
(1999-2001)\end{array}$ \\
\hline
\end{tabular}




\begin{tabular}{|c|c|c|c|}
\hline $\begin{array}{c}\text { Kelembagaan Urusan } \\
\text { Pangan }\end{array}$ & Tugas dan Wewenang & $\begin{array}{c}\text { Dasar Hukum } \\
\text { Penetapan }\end{array}$ & $\begin{array}{c}\text { Pemerintahan/ } \\
\text { Tahun } \\
\text { Ditetapkan }\end{array}$ \\
\hline & $\begin{array}{l}\text { 4)pengembangan industri berbasis beras, } \\
\text { termasuk produksi padi/gabah; } \\
\text { 5)pengolahan gabah dan beras; } \\
\text { 6)pengembangan pergudangan beras. } \\
\text { Tugas khusus: } \\
\text { 1)pengamanan harga pangan lainnya; } \\
\text { 2)pengelolaan cadangan pangan } \\
\text { Pemerintah untuk pangan lainnya; } \\
\text { 3)penyediaan dan pendistribusian } \\
\text { pangan lainnya; } \\
\text { 4)pelaksanaan impor pangan lainnya } \\
\text { dalam rangka pelaksanaan tugas sesuai } \\
\text { ketentuan peraturan perundang- } \\
\text { undangan; } \\
\text { 5)pengembangan industri berbasis } \\
\text { pangan lainnya; } \\
\text { 6)pengembangan pergudangan pangan } \\
\text { lainnya. }\end{array}$ & & \\
\hline \multirow[t]{2}{*}{ Badan Urusan Logistik } & $\begin{array}{l}\text { Tugas pokok Bulog adalah dalam rangka } \\
\text { tugas pemeirntahan bidang menajemen } \\
\text { logistik. } \\
\text { Kewenangan antara lain: 1) perumusan } \\
\text { dan pelaksanaan kebijakan tertentu di } \\
\text { bidang manajemen logistik, pengadaan, } \\
\text { pengelolaan persediaan, dan distribusi } \\
\text { beras serta pengendalian harga beras; 2) } \\
\text { perumusan norma dan pengadaan, } \\
\text { pengelolaan dan distribusi beras. }\end{array}$ & $\begin{array}{l}\text { Keppres No.103 Tahun } \\
2001 \text { Pasal 40-42. }\end{array}$ & $\begin{array}{l}\text { Presiden } \\
\text { Megawati } \\
\text { Sukarnoputri } \\
(2001)\end{array}$ \\
\hline & 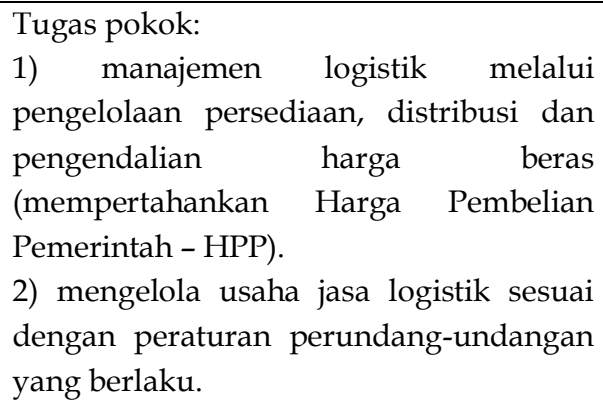 & $\begin{array}{l}\text { Keppres No. } 03 \text { Tahun } \\
2002 \text { Tgl.7 Januari } 2002 .\end{array}$ & $\begin{array}{l}\text { Presiden } \\
\text { Megawati } \\
\text { Soekarnoputri } \\
(2002)\end{array}$ \\
\hline $\begin{array}{l}\text { Perusahaan Umum } \\
\text { Badan Urusan Logistik }\end{array}$ & $\begin{array}{l}\text { Tugas pokok: } \\
\text { 1)menyediakan pelayanan bagi } \\
\text { kemanfaatan umum dan sekaligus } \\
\text { memupuk keuntungan berdasarkan } \\
\text { prinsip pengelolaan perusahaan; } \\
\text { 2)menyelenggarakan usaha logistik } \\
\text { pangan pokok yang bermutu dan } \\
\text { memadai bagi pemenuhan hajat hidup } \\
\text { orang banyak; hal tertentu melaksanakan } \\
\text { 3)dalam hal } \\
\text { tugas-tugas tertentu yang diberikan } \\
\text { Pemerintah dalam pengamanan harga }\end{array}$ & $\begin{array}{l}\text { PP No. } 7 \text { Tahun } 2003 \\
\text { tentang Bulog. }\end{array}$ & $\begin{array}{l}\text { Presiden } \\
\text { Megawati } \\
\text { Soekarnoputri } \\
(2003)\end{array}$ \\
\hline
\end{tabular}




\begin{tabular}{|c|c|c|c|}
\hline $\begin{array}{l}\text { Kelembagaan Urusan } \\
\text { Pangan }\end{array}$ & Tugas dan Wewenang & $\begin{array}{l}\text { Dasar Hukum } \\
\text { Penetapan }\end{array}$ & $\begin{array}{c}\text { Pemerintahan/ } \\
\text { Tahun } \\
\text { Ditetapkan }\end{array}$ \\
\hline & $\begin{array}{l}\text { pangan pokok, } \\
\text { 4)Mengelola Cadangan Pangan } \\
\text { Pemerintah }(\mathrm{CPP}) \text {, dan distribusi pangan } \\
\text { pokok kepada golongan masyarakat } \\
\text { tertentu, khususnya pangan pokok beras } \\
\text { dan pangan pokok lainnya yang } \\
\text { ditetapkan oleh Pemerintah dalam } \\
\text { rangka ketahanan pangan. } \\
\text { Tujuan perusahaan adalah turut serta } \\
\text { membangun ekonomi nasional } \\
\text { khususnya dalam rangka pelaksanaan } \\
\text { program pembangunan nasional di } \\
\text { bidang pangan. }\end{array}$ & & \\
\hline $\begin{array}{l}\text { Perusahaan Umum } \\
\text { Badan Urusan Logistik }\end{array}$ & - & - & $\begin{array}{l}\text { Presiden Susilo B. } \\
\text { Yudhoyono } \\
(2004-2014)\end{array}$ \\
\hline $\begin{array}{l}\text { Perusahaan Umum } \\
\text { Badan Urusan Logistik }\end{array}$ & - & $\begin{array}{l}\text { Instruksi } \quad \text { Presiden } \\
\text { Nomor } 5 \text { Tahun } 2015\end{array}$ & $\begin{array}{l}\text { Presiden Joko } \\
\text { Widodo (2015) }\end{array}$ \\
\hline $\begin{array}{l}\text { Perusahaan Umum } \\
\text { Badan Urusan Logistik }\end{array}$ & $\begin{array}{l}\text { Tugas pokok: } \\
\text { 1)pengamanan harga pangan pokok } \\
\text { beras ditingkat produsen dan konsumen; } \\
\text { 2)pengelolaan cadangan pangan pokok } \\
\text { beras Pemerintah; } \\
\text { 3)penyediaan dan pendistribusian } \\
\text { pangan pokok beras kepada golongan } \\
\text { masyarakat tertentu; } \\
\text { 4)pelaksanaan impor beras dalam rangka } \\
\text { pelaksanaan sesuai dengan ketentuan } \\
\text { peraturan perundang-undangan; } \\
\text { 5)pengembangan industri berbasis beras, } \\
\text { termasuk produksi padi/gabah serta } \\
\text { pengolahan gabah dan beras; } \\
\text { 6)pengembangan pergudangan beras. } \\
\text { Tugas khusus: } \\
\text { 1)pengamanan harga pangan lainnya; } \\
\text { 2)pengelolaan cadangan pangan } \\
\text { Pemerintah untuk pangan lainnya; } \\
\text { 3)penyediaan dan pendistribusian } \\
\text { pangan lainnya; } \\
\text { 4)pelaksanaan impor pangan lainnya } \\
\text { dalam rangka pelaksanaan tugas sesuai } \\
\text { ketentuan peraturan perundang- } \\
\text { undangan; } \\
\text { 5)pengembangan industri berbasis } \\
\text { pangan lainnya; } \\
\text { 6)pengembangan pergudangan pangan } \\
\text { lainnya. }\end{array}$ & $\begin{array}{l}\text { PP No.13 Tahun } 2016 \\
\text { tentang Bulog. }\end{array}$ & $\begin{array}{l}\text { Presiden } \quad \text { Joko } \\
\text { Widodo } \\
(2016)\end{array}$ \\
\hline $\begin{array}{l}\text { Perusahaan Umum } \\
\text { Badan Urusan Logistik }\end{array}$ & $\begin{array}{l}\text { Tugas pokok: } \\
\text {-Menjaga ketersediaan pangan dan }\end{array}$ & $\begin{array}{l}\text { PerPres No.48 Tahun } \\
2016 \text { tentang Penugasan }\end{array}$ & $\begin{array}{l}\text { Presiden Joko } \\
\text { Widodo }\end{array}$ \\
\hline
\end{tabular}




\begin{tabular}{|l|l|l|l|}
\hline $\begin{array}{c}\text { Kelembagaan Urusan } \\
\text { Pangan }\end{array}$ & \multicolumn{1}{|c|}{ Tugas dan Wewenang } & $\begin{array}{c}\text { Dasar Hukum } \\
\text { Penetapan }\end{array}$ & $\begin{array}{c}\text { Pemerintahan/ } \\
\text { Tahun } \\
\text { Ditetapkan }\end{array}$ \\
\hline & $\begin{array}{l}\text { stabilitas harga pangan di tingkat } \\
\text { produsen dan konsumen untuk } \\
\text { komoditas beras, jagung, dan kedelai. }\end{array}$ & $\begin{array}{l}\text { Kepada Bulog Dalam } \\
\text { Rangka Ketahanan } \\
\text { Pangan Nasional }\end{array}$ & (2016) \\
\hline
\end{tabular}

Keterangan: *) Sejak 1967-2002 Bulog berbentuk lembaga pemerintah non-departemen. Keppres RI No.103 Tahun 2001 menegaskan bahwa Bulog harus beralih status menjadi BUMN selambat-lambatnya 31 Mei 2003.

Sumber: Diolah dari Berbagai Sumber

Setelah mundurnya Presiden Suharto pada Mei 1998 dan digantikan oleh BJ. Habibie, eksistensi Bulog masih dipertahankan. Tugas dan kewenangannya masih sangat terbatas sesuai Keppres No.19 Tahun 1998. Bulog masih berbentuk lembaga pemerintah nondepartemen.

Pada masa pemerintahan Presiden Abdurrahman Wahid, Bulog juga masih dipertahankan. Tetapi kemudian pemerintah mengeluarkan Keppres No. 29 dan No.166 Tahun 2000. Tugas dan fungsi Bulog hanya menangani komoditas beras termasuk menjaga stabilitas harga beras di pasar. Keppres tersebut tidak secara tegas dan tidak dinyatakan bahwa impor beras dilarang. Walaupun Presiden sudah mengeluarkan 2 keppres tentang Bulog pada tahun 2000, tetapi impor beras sejak 2000 sudah mulai dilaksanakan sampai pemerintahan Presiden SBY. Berdasarkan data BPS Pusat, jumlah impor beras tahun 2000 sebesar 4,7 juta ton. Impor beras terbesar berasal dari Vietnam (38\%), Thailand $(28,90 \%)$, dan sisanya dari negara Asia lainnya.

Menurut Keppres No.166 Tahun 2000 bahwa Bulog mempunyai tugas pokok melaksanakan tugas pemerintahan dan pembangunan di bidang manajemen logistik sesuai dengan peraturan perundang-undangan yang berlaku. Dari isi aturan, fungsi Bulog sebatas manajemen logistik atau dapat dikatakan hanya sebagai pedagang pengumpul komoditi pangan. Komoditi pangan yang termasuk dalam wewenang Bulog hanya beras saja. Untuk komoditi non-beras Bulog tidak memiliki wewenang melaksanakan tugas pokoknya. Padahal sebelum Keppres No.166
Tahun 2000, Bulog memiliki fungsi sebagai badan penstabil harga pangan tidak hanya beras. Hal tersebut menjadi kontradiksi ketika Bulog yang merupakan lembaga pemerintah urusan pangan tidak mampu menjadi badan penstabil harga.

Sebagaimana dengan rezim pemerintahan sebelumnya, tugas dan fungsi Bulog selalu mengalami perubahan. Presiden Megawati mengeluarkan Keppres No.03 Tahun 2002 Tgl.7 Januari 2002 untuk menggantikan Keppres Nomor 29 dan Nomor 166 Tahun 2000 yang dikeluarkan oleh Presiden sebelumnya. Berdasarkan Keppres di atas, tugas dan fungsi Bulog sangat general dan juga tidak secara tegas dinyatakan. Intinya adalah Bulog masih menangani urusan perberasan termasuk distribusi beras untuk golongan masyarakat tertentu atau yang disebut dengan Raskin.

Kemudian pada tahun 2003, Presiden Megawati mengeluarkan PP Nomor 7 Tahun 2003 tentang Perusahaan Umum Bulog. Pada saat inilah Bulog berubah status dan bentuk hukum dari lembaga pemerintah nondepartemen menjadi badan usaha milik negara berbentuk Perum. Tetapi regulasi ini juga tidak menjelaskan secara konkrit tugas dan kewenangan Bulog sebagai badan usaha untuk mengurus komoditas pangan pokok. Sejak 2003 sampai 2015, urusan pangan pokok masih didasarkan pada peraturan pemerintah tersebut yakni tugas dan wewenang untuk menyelenggarakan usaha logistik pangan pokok dan usaha-usaha lain. Pasal 6 ayat 2 (b) PP Nomor 7 Tahun 2003 di atas ditegaskan, dalam hal tertentu, Perum.Bulog melaksanakan tugas-tugas tertentu yang diberikan Pemerintah 
dalam pengamanan harga pangan pokok, pengelolaan Cadangan Beras Pemerintah (CBP), dan distribusi pangan pokok kepada golongan masyarakat tertentu, khususnya pangan pokok beras dan pangan pokok lainnya yang ditetapkan oleh Pemerintah dalam rangka ketahanan pangan (Raskin). Dari pasal tersebut juga tidak secara tegas Perum.Bulog bertanggungjawab menangani komoditas pangan pokok lain di luar beras. Artinya harga komoditas pangan lain di luar beras diserahkan kepada mekanisme pasar bebas. Walaupun Bulog telah berubah menjadi perusahaan umum, tetapi Bulog masih belum mampu untuk menjamin stabilitas harga pangan pokok di luar beras di pasar. Hal inilah yang menyebabkan sebagan besar harga pangan melonjak hampir setiap tahun terutama di hari keagamaan seperti ramadhan, Natal dan Tahun Baru dan sulit untuk turun walau dalam kondisi pasar relatif stabil.

Pada masa pemerintahan Presiden SBY (2004-2014), upaya pemberdayaan kelembagaan pangan juga terus dilakukan. Pada masa Presiden SBY, pemerintah mengeluarkan Perpres Nomor 32 Tahun 2013 tentang Penugasan kepada Perum Bulog untuk pengamanan harga dan penyaluran kedelai. Namun komoditas yang ditetapkan hanya kedelai. Penugasan tersebut juga tergantung kepada kebijakan Menteri Perdagangan dan rekomendasi Menteri Pertanian. Tampak bahwa Perpres ini tidak kuat dalam menjaga stabilitas harga kedelai. Di samping itu, Bulog tidak secara tegas diberi kewenangan untuk impor kedelai, tetapi dapat bertindak sebagai distributor utama kedelai untuk pasar dalam negeri. Bulog juga dapat bekerja sama dengan badan usaha lain dalam mendsitribusikan kedelai.

Kemudian Presiden SBY tahun 2006 membentuk Dewan Ketahanan Pangan (DKP) melalui Perpres Nomor 83 Tahun 2006. Perpres ini menggantikan Keppres Nomor 132 Tahun 2001 sebagai pelaksanaan dari UU Nomor 7 Tahun 1996 tentang Pangan. Berdasarkan
Perpres ini, tugas DKP adalah: 1) Merumuskan kebijakan dalam rangka mewujudkan ketahanan pangan nasional; 2) Melaksanakan evaluasi dan pengendalian dalam rangka mewujudkan ketahanan pangan nasional. Tugas DKP meliputi kegiatan: penyediaan pangan, distribusi pangan, cadangan pangan, penganekaragaman pangan, pencegahan, dan penanggulangan masalah pangan dan gizi.

Dalam menrespon dan antisipasi terhadap kondisi iklim ekstrem, pemerintahan SBY tahun 2011 menugaskan Perum.Bulog untuk mengamankan cadangan beras pemerintah melalui Instruksi Presiden No.8 Tahun 2011 yang jumlahnya ditetapkan Menteri Pertanian. Di samping itu, Perum.Bulog juga ditugaskan mengamankan cadangan beras untuk masyarakat golongan tertentu (Raskin). Sedangkan Pembelian gabah/beras oleh Perum.Bulog dalam rangka pengamanan cadangan beras pemerintah dilakukan dengan memperhatikan Harga Pembelian Pemerintah (HPP). Dalam hal harga pasar gabah/beras lebih tinggi dari HPP, pembelian gabah/beras dapat dilakukan oleh Perum.Bulog pada harga yang lebih tinggi dari HPP dengan memperhatikan harga pasar yang dicatat oleh Badan Pusat Statistik. Fungsi Perum.Bulog dalam hal ini masih tetap dilaksanakan sesuai dengan tugas dan kewenangannya. Untuk melaksanakan tugas tersebut, Menteri Keuangan mengalokasikan anggaran yang diperlukan untuk pengadaan gabah/beras dalam rangka penugasan Pemerintah kepada Perum.Bulog sesuai dengan kemampuan keuangan negara dalam APBN.

Kemudian tahun 2012, pemerintahan SBY mengganti UU No.7 Tahun 1996 dengan UU No.18 Tahun 2012 tentang Pangan. Dalam Pasal 126-128 tidak dinyatakan secara konkrit lembaga pangan yang dimaksud dalam UU tersebut. Lembaga pangan sesuai pasal tersebut di atas merupakan lembaga pemerintah dan bukan badan usaha. Lembaga pangan pemerintah tersebut dapat menugaskan kepada BUMN untuk melakukan tugas-tugas pangan 
sebagaimana diatur dalam undang-undang di atas. Dari pasal di atas, kecenderungan untuk multi-tafsir dapat terjadi yakni lembaga pemerintah dimaksud dapat merupakan Kementerian Pertanian atau BKP atau Kementerian Perdagangan.

Seperti halnya UU No.7 Tahun 1996, UU No.18 Tahun 2012 juga tidak anyak mengatur secara rinci, jelas dan detail soal lembaga pangan. Padahal urusan pangan sangat kompleks dan lintas-sektor. Sebelum lahirnya UU No.7 Tahun 1996 memang belum ada peraturan perundang-undangan yang mengatur kelembagaan pangan. Tetapi dapat dilihat bahwa pemerintah perlu lebih tegas dan berwibawa dalam mengurus pangan, tidak hanya mengatur dari sisi hulu semata (produksi) tetapi juga dari sisi hilir (distribusi/supply) dalam hal ini Bulog.

Masalah pangan di sisi hulu telah menjadi tanggungjawab dan domain Kementerian Pertanian di pusat maupun daerah sebagai regulator. Tetapi dari sisi hilir pemerintah tidak hanya sebagai regulator, tetapi perlu "intervensi" dengan menguatkan BUMN Perum. Bulog dalam kegiatan usaha hilir pangan. Kerumitan dan persoalan yang paling banyak di sektor pangan adalah di sisi hilir. Walaupun dari sisi hulu pemerintah "sudah" mampu menanganinya, tetapi di sisi hilir seperti tata niaga pangan, pemerintah belum mampu menanganinya termasuk komoditas beras yang sudah sejak bertahun-tahun ditangani oleh pemerintah melalui Bulog sampai periode pemerintahan Presiden SBY 2004-2014.

Sejak Presiden Soekarno sampai Presiden SBY, pemerintah sudah mengeluarkan 15 peraturan perundang-undangan tentang kelembagaan pangan di luar Departemen pertanian/Kementerian Pertanian. Mulai dari keputusan presiden sampai peraturan pemerintah dan undang-undang. Di satu sisi hal ini menunjukkan positif dan besarnya perhatian pemerintah mengenai pangan, tetapi di sisi lain seringnya pergantian peraturan perundang-undangan, menyebabkan urusan pangan menjadi tidak fokus dan juga berubahubah sesuai dengan rezim pemerintahan yang berkuasa. Tetapi diakui tidak secara jelas dan tegas kelembagaan pangan diatur dalam undang-undang tentang pangan baik UU No.7 Tahun 1996 maupun UU No.18 Tahun 2012. Ketidaktegasan dan ketidakjelasan pengaturan secara konkrit pengaturan kelembagaan pangan dalam suatu UU akan mempengaruhi implementasi kebijakan dan program pemerintah dalam urusan pangan. Sebab tidak mungkin urusan pangan sepenuhnya diserahkan kepada mekanisme pasar bebas. Masih dibutuhkan intervensi pemerintah baik dalam sisi hulu (Kementerian Pertanian) maupun sisi hilir (Bulog).

Masa Presiden Joko Widodo misalnya, pemerintah sudah mengeluarkan 3 bentuk peraturan perundang-undangan di luar undang-undang, yakni Instruksi Presiden No.5 Tahun 2015 tentang Kebijakan pengadaan gabah/beras dan penyaluran beras oleh pemerintah melalui Perum.Bulog, PP No.13 Tahun 2016, dan Perpres No.48 Tahun 2016. Sedangkan Perpres No.48 Tahun 2016-yang dikeluarkan untuk melaksanakan ketentuan Pasal 3 dari Peraturan Pemerintah No.13 Tahun 2016. Ketiga peraturan di atas menugaskan dan memberi kewenangan kepada Perum.Bulog untuk mengurus pangan, tidak hanya komoditas beras.

Beberapa keuntungan Bulog dengan perubahan departemen menjadi Perum adalah: pertama, Bulog dapat menjalankan tugas-tugas tertentu yang diberikan pemerintah seperti pengamanan harga pangan pokok, menyelenggarakan logistik pangan termasuk cadangan beras pemerintah, dan distribusi beras serta komoditas pangan pokok lainnya untuk golongan masyarakat tertentu. Kedua, Bulog dapat menjalankan fungsi bisnis sesuai UU tentang BUMN karena ruang gerak sebagai badan usaha lebih fleksibel tanpa mengesampingkan tugas publik. Ketiga, Bulog dapat bertindak sebagai distributor tunggal 
dalam komoditas pangan pokok karena memang diperbolehkan dalam UU No.5 Tahun 1999 tentang Anti-Monopoli.

Lahirnya PP No.13 Tahun 2016 tentang Perum.Bulog merupakan entry point dalam menata dan mencari solusi tata niaga pangan pokok ke depan terutama dari sisi hilir. Tetapi salah satu persoalan di lapangan adalah, tidak adanya data yang akurat mengenai berapa jumlah rata-rata kebutuhan/permintaan setiap jenis komoditas pokok dan berapa jumlah stok kebutuhan pokok yang ada di pasar baik di tingkat produsen, di tingkat distributor maupun pedagang kecil/eceran per hari. Apabila hal ini dapat diketahui dengan tingkat error yang relatif kecil, maka akan dapat dijadikan sebagai masukan dalam pengambilan kebijakan ke depan. Apabila tugas dan kewenangan Perum.Bulog dalam PP No. 7 Tahun 2003 dengan PP No. 13 Tahun 2016, berbeda, maka perbedaan tersebut turut menyebabkan fungsi dan kredibilitas Perum.Bulog dalam menjaga supply dan stabilitas harga pangan pokok menjadi tidak optimal dan tidak maksimal.

Untuk memperkuat tugas, dan wewenang Bulog pemerintah dengan pertimbangan memperkuat struktur permodalan dan meningkatkan kapasitas usaha, Presiden Joko Widodo mengeluarkan PP No.49 Tahun 2015 tentang Penambahan Penyertaan Modal Negara ke Dalam Modal Perusahaan Umum (Perum) Bulog senilai Rp3 triliun dari APBN Tahun Anggaran 2015.

Kemudian dalam konteks hulu, Kementerian Pertanian juga telah memiliki visi dan program pembangunan pertanian dalam Renstra 2015-2019, yakni “Terwujudnya sistem pertanian-bio-industry berkelanjutan yang menghasilkan beragam pangan sehat dan produk bernilai tambah tinggi berbasis sumberdaya lokal untuk kedaulatan pangan dan kesejahteraan petani". Renstra Pertanian 2015-2019 adalah: 1) Swasembada padi, jagung, dan kedelai serta peningkatan produksi daging dan produksi gula; 2) Peningkatan diversifikasi pangan; 3) Peningkatan nilai tambah, daya saing, ekspor, dan substitusi impor; 4) Penyediaan bahan baku bio-industry dan bioenergy; 5) Peningkatan pendapatan dan kesejahteraan petani.

\section{Bulog Dalam Pilar Ketahanan Pangan: Program Raskin}

Pemerintah saat ini senantiasa tetap menjaga ketahanan pangan setiap rumah tangga, salah satunya melalui komoditas beras untuk rumah tangga miskin. Dari sisi ketersediaan, pemerintah melalui Inpres No. 3 Tahun 2012 memberikan jaminan harga dan pasar bagi hasil produksi petani melalui penyerapan/pengadaan oleh Perum.Bulog sehingga petani memiliki semangat untuk terus berproduksi. Peningkatan produksi padi (gabah) akan memperkuat ketersediaan beras dalam negeri tanpa tergantung pada impor. Dari sisi keterjangkauan, pemerintah telah menyediakan beras di setiap rumah tangga dengan harga terjangkau, khusus bagi rumah tangga miskin. Program Raskin tersedia di dekat rumah tangga miskin dengan harga yang lebih rendah dari harga di pasar. Sedangkan untuk menjamin stabilitas pasokan dan harga beras, pemerintah melalui Perum.Bulog telah melakukan pemerataan stok dengan tersedianya beras di setiap gudang Perum Bulog di seluruh Indonesia.

Dari sisi rumah tangga miskin, peran Bulog telah membuka akses secara ekonomi dan fisik terhadap pangan, sehingga dapat melindungi rumah tangga rawan pangan dari malnutrition terutama energi dan protein. Hal ini sangat penting bagi negara berkembang seperti Indonesia yang menghadapi permasalahan masyarakat yang kekurangan energi dan protein. Kekurangan tersebut dapat berakibat buruk terhadap kecerdasan anak, rendahnya produktivitas SDM, dan kematian sebagai akibat penyakit infeksi karena lemahnya daya tahan tubuh.

Raskin saat ini telah menjadi program perlindungan sosial atau jaring pengaman social (social protection programme). Bukan lagi sebagai 
program darurat pangan pada awalnya. Dengan demikian Raskin - sebagai bagian dari strategi ketahanan pangan pemerintah, telah diakui memiliki dampak dalam perkonomian dan perberasan nasional. Program Raskin yang dijalankan Bulog-dalam kontek ketahanan pangan merupakan program yang multiobjektif yaitu: pertama, menjaga ketahanan pangan keluarga miskin; Kedua, berfungsi sebagai pendukung peningkatan kualitas SDM masyarakat miskin; Ketiga, secara tidak langsung berperan menjaga stabilitas ekonomi makro; Keempat, memiliki keunggulan sebagai program yang bersifat "people oriented" dengan sasaran yang jelas berupa RTM; Kelima,program Raskin juga bersifat "commodity oriented" berbasis komoditas beras yang merupakan bahan pokok strategis. Keenam, program Raskin juga menyertakan partisipasi yang luas, mulai dari pemerintah pusat (Bulog), pemerintah daerah, serta masyarakat.

Raskin juga memiliki dampak langsung terhadap harga beras di pasar. Hal ini terlihat saat Raskin hanya diberikan 10 atau 11 bulan pada tahun 2006 dan 2007, harga beras di akhir tahun melonjak lebih tajam. Umumnya pada akhir tahun adalah musim paceklik, sehingga suplai beras ke pasar berkurang. Namun dari sisi permintaan, rumah tangga sasaran yang biasanya menerima Raskin, tidak lagi mendapat Raskin sehingga belasan juta rumah tangga menambah permintaan beras ke pasar. Kekurangan suplai di satu sisi dan peningkatan permintaan di sisi lain mengakibatkan harga beras naik sejak 2014.

Dalam UU No.18 Tahun 2012 tentang Pangan diamanatkan bahwa pemerintah bersama masyarakat bertanggungjawab mewujudkan ketahanan pangan. Hal ini dapat diartikan bahwa ketahanan pangan tidaklah sepenuhnya diserahkan pada mekanisme pasar seperti yang dilakukan sebagian negara maju dan liberal. Apabila hal ini ditempuh maka dapat berakibat buruk pada kelompok masyarakat miskin yang jumlahnya masih dominan. Keberadaan masyarakat miskin tersebut terpencar di seluruh wilayah Indonesia dengan keterbatasan infrastruktur transportasi dan komunikasi. Dengan mewujudkan ketahanan pangan yang tangguh, masyarakat yang rawan pangan tersebut dapat terlindungi dengan baik. Dalam hal ini fungsi Perum.Bulog sangat penting dan strategis.

Sejumlah negara di Asia juga memberlakukan berbagai kebijakan pangan guna melindungi petani produsen, konsumen ataupun keduanya secara simultan baik melalui fungsi penetapan harga pembelian pemerintah (HPP), penyediaan stok, ataupun penyaluran/distribusi pangan dalam rangka menjamin stabilisasi harga konsumen. Intervensi (negara) tersebut dilaksanakan melalui berbagai lembaga pangan pemerintah, baik yang berbentuk seperti BUMN yaitu Public Warehouse Organisation (PWO) di Thailand, semacam LPND seperti National Food Authority di Philipina, ataupun berbentuk perusahaan terbuka seperti Bernas di Malaysia. Meskipun terdapat perbedaan status lembaga operator bidang pangan yang melaksanakan fungsi intervensi di pasar di 3 negara di atas, namun di masing-masing lembaga tersebut secara jelas disebutkan kewajiban dan hak-hak yang diberikan kepada operator dari pemerintah yang menugaskan. Dengan demikian, terdapat kejelasan tentang hal-hal yang perlu dilakukan oleh operator serta kejelasan hak-hak yang diberikan kepada lembaga operator, termasuk segala beban (biaya/anggaran) yang timbul akibat penugasan tersebut.

\section{Pengadaan Gabah/Beras Dalam Negeri: Pilar} Ketersediaan

Penguatan Bulog melalui pengadaan gabah/beras dalam negeri dipercaya akan dapat mewujudkan amanat dalam UU No.18 Tahun 2012 tentang Pangan yakni mewujudkan kedaulatan, kemandirian, dan ketahanan pangan nasional. Dalam kaitan ini, Presiden Joko Widodo telah menandatangani Perpres No.48 Tahun 2016 tentang Penugasan kepada Perum.Bulog dalam rangka ketahanan pangan nasional. Perpres ini memberikan tugas dan 
tanggung jawab baru kepada Perum Bulog bahwa pengadaan pangan diutamakan melalui pengadaan pangan dari dalam negeri. Dalam hal pengadaan pangan dalam negeri-jika tidak mencukupi, maka dapat dilakukan pengadaan pangan dari stok operasional Perum.Bulog maupun dari luar negeri dengan tetap menjaga kepentingan produsen dan konsumen dalam negeri.

Tugas publik Perum.Bulog merupakan amanat dari Inpres Nomor 3 Tahun 2012 tentang Kebijakan Pengadaan Gabah/Beras dan Penyaluran Beras oleh Pemerintah, yang merupakan pengejawantahan intervensi pemerintah dalam perberasan nasional untuk memperkuat ketahanan pangan. Tugas dan tanggungjawab publik Perum.Bulog tersebut saling terkait dan memperkuat satu sama lain sehingga dapat mewujudkan ketahanan pangan rumah tangga maupun nasional yang lebih kokoh. Ketiga tugas publik tersebut adalah pertama, melaksanakan kebijakan pembelian gabah/beras dalam negeri dengan ketentuan Harga Pembelian Pemerintah (HPP). Kegiatan ini diwujudkan dalam bentuk pengadaan gabah dan beras dalam negeri oleh Perum.Bulog. Kedua, menyediakan dan menyalurkan beras bersubsidi bagi kelompok masyarakat berpendapatan rendah yang diwujudkan dalam pelaksanaan program Raskin. Sedangkan Ketiga, menyediakan dan menyalurkan beras untuk menjaga stabilitas harga beras, menanggulangi keadaan darurat, bencana, dan rawan pangan. Kegiatan ketiga dilaksanakan Perum Bulog dalam bentuk pengelolaan Cadangan Beras Pemerintah (CBP).

Konsep pengadaan gabah dan beras dalam negeri dilakukan pemerintah sebagai intervensi dari sisi produsen pada saat supply beras melimpah karena panen raya. Untuk melindungi petani dari tingkat harga yang rendah karena kurang kuatnya nilai tawar petani saat panen, pemerintah menggunakan instrumen $\mathrm{HPP}$-sebelumnya Harga Dasar (HD). Dengan instrumen HPP ini, diharapkan pasar akan menjadikan HPP sebagai patokan dalam membeli gabah dan beras petani sehingga petani menjadi terlindungi. Selain itu, pengadaan oleh Perum.Bulog juga dapat menjadi salah satu alternatif pasar bagi produksi petani dalam negeri. Dengan demikian, pengadaan dalam negeri akan mampu menjadi jaminan pasar dan harga bagi produksi dalam negeri sehingga petani masih tetap bersemangat untuk memproduksi pangan (beras) dalam negeri untuk menjaga ketersediaan pasokan pangan nasional. Melalui pengadaan gabah dan beras dalam negeri, pilar ketersediaan ketahanan pangan dapat diwujudkan. Di bawah ini digambarkan alur pengadaan gabah/beras oleh Bulog guna memperkuat ketersediaan beras di masyarakat melalui peran Bulog.

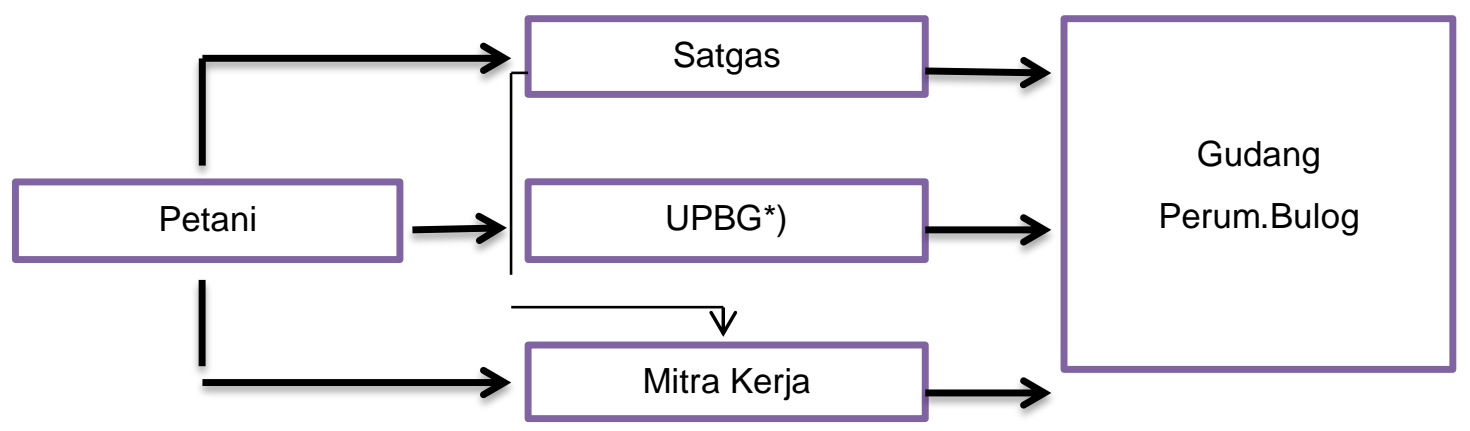

Keterangan: *) Unit Pengolahan Beras dan Gabah Bulog

Gambar 2. Alur Pengadaan Beras/gabah oleh Perum Bulog dari Petani

Sumber: www.bulog.co.id 
Selama ini, pengamanan HPP dilakukan Perum.Bulog melalui pembelian gabah/beras dalam negeri terutama saat panen raya. Mengikuti perkembangan produksi beras yang naik tajam dalam tiga tahun terakhir ini, maka penyerapan pemerintah melalui pengadaan dalam negeri oleh Perum.Bulog menjadi salah satu hal penting. Pasokan yang melimpah terutama saat panen raya, mengakibatkan terjadinya surplus di pasar yang perlu penyerapan. Keberhasilan Perum.Bulog dalam menghimpun stok dari pengamanan HPP membantu dalam memperkuat stok beras nasional, juga membantu peningkatan pendapatan jutaan petani yang tersebar di berbagai tempat di tanah air dan sekaligus dapat mendorong stabilitas harga beras. Hal ini tergambar dalam alur pengadaan beras oleh Bulog di atas. (Lihat gambar 2). Bulog tidak hanya membeli beras tetapi juga membeli gabah petani dan kemudian diolah menjadi beras melalui UPBG Bulog yang kemudian disimpan di gudang Bulog. Peningkatan stok Bulog adalah guna mewujudkan ketersediaan pangan (availability) untuk masyarakat.

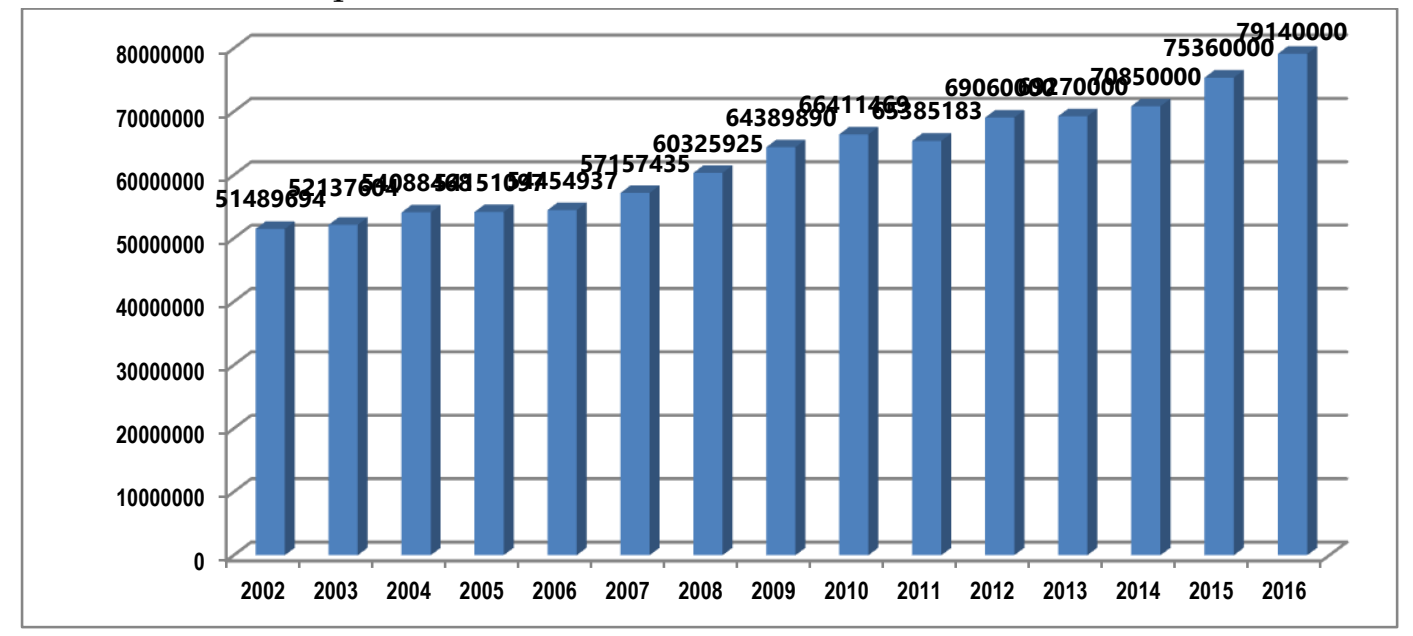

Gambar 3. Produksi Padi (gabah kering giling) Indonesia Periode 2002-2016

Sumber: diolah dari data Bulog

Pembelian atau pengadaan bagah/beras oleh Perum.Bulog selama ini rata-rata mencapai sekitar 5\%-9\% dari total produksi beras nasional setiap tahunnya atau sekitar 1,5-3 juta ton setara beras per tahun, terbesar di antara firm yang ada di dalam industri padi/beras nasional. Dengan besarnya pembelian ini, maka HPP dapat menjadi patokan bagi pembelian gabah dan beras di pasar umum. Hal ini terlihat dari perkembangan harga gabah dan beras di pasar yang selalu di atas Harga Pembelian Pemerintah. Dana pengadaan dalam negeri yang mengalir ke pedesaan mencapai Rp6-7 triliun selama 4-5 bulan periode pengadaan. Berbagai kajian menyebutkab bahwa multiplier effect dari kegiatan pengadaan gabah dan beras dalam negeri diantaranya adalah mampu menggerakkan perekonomian pedesaan dan mendorong pembangunan pedesaan dengan mengalir sekitar Rp. 19 triliun melalui peningkatan pendapatan dan perluasan lapangan kerja. Pengadaan juga berfungsi mendorong harga produsen agar memberi keuntungan dan insentif bagi usaha tani padi, yang juga berarti meningkatkan kesejahteraannya.

Strategi stabilisasi harga beras oleh Bulog sejak menjadi badan usaha dilakukan melalui operasi pasar yang terdiri dari: 1) operasi pasar kontrak; 2)operasi pasar murni melalui distributor/retailer; 3)operasi pasar murni melalui Satgas Bulog; 4)operasi pasar khusus; 4)Program Raskin yang dilaksanakan oleh Perum.Bulog misalnya, adalah bertujuan untuk 
memperkuat pilar keterjangkauan (accessibilty) pangan pokok bagi masyarakat. Beras pengadaan dalam negeri diantaranya disalurkan langsung oleh Bulog kepada Rumah Tangga Miskin yang menjadi sasaran program penanggulangan kemiskinan. Dengan nama program Raskin-beras untuk Rumah Tangga Miskin diharapkan setiap Rumah Tangga Sasaran mampu memperoleh ketahanan pangannya tidak lagi dengan membeli beras di pasar dengan harga relatif mahal tetapi ke Perum.Bulog sehingga hal ini akan mengurangi permintaan beras ke pasar. Strategi ini paling tidak secara psikologis akan meredam gejolak pasar komoditas beras.

\section{Cadangan Beras Pemerintah: Memperkuat Pilar Stabilitas Harga}

Cadangan beras pemerintah sangat diperlukan untuk memperkuat ketahanan pangan rumah tangga dalam situasi darurat seperti bencana alam banjir; kekeringan, serangan hama/ penyakit, gunung meletus, dan sebagainya, serta bencana yang dibuat manusia (konflik sosial). Cadangan beras pemerintah yang dikelola Bulog juga berperan mengatasi kondisi rawan daya beli masyarakat akibat gejolak harga pangan yang tinggi (inflatoir). Dengan menyatunya stok cadangan beras pemerintah di Bulog secara fisik (secara administrasi terpisah), pemerintah akan mudah untuk memanfaatkan beras tersebut apabila diperlukan setiap saat, setiap tempat, sehingga rumah tangga masih terutama masyarakat miskin dan hampir miskin, tetap memiliki akses terhadap pangan pokok. Dengan cadangan beras pemerintah yang tersedia setiap saat, di setiap tempat, maka stabilitas pangan (beras) nasional dapat terwujud. Rumah tangga pada situasi darurat dan saat terjadi kenaikan harga pangan yang tinggi dapat mengharapkan stabilitas pasokan dan harga dari cadangan beras pemerintah ini. Dengan demikian dapat menjadi salah satu alat memperkuat pilar stabilitas ketahanan pangan. Kebijakan cadangan beras pemerintah ini telah teruji saat terjadinya bencana Tsunami di NAD dan Nias pada akhir 2004 dan awal 2005, gempa bumi di Yogyakarta dan Jateng, kekeringan di NTT, korban banjir di Kabupaten Kutai, korban kebakaran di Riau dan Kalimantan Barat. Dengan cadangan beras yang terpusat pengelolaannya di Bulog, maka akan memudahkan pemerintah untuk menangani situasi darurat. Ini sebagai bentuk kepedulian pemerintah pusat terhadap daerah di era otonomi, sehingga hal itu dapat membuat sebagai perekat nasional dan menjaga ketahanan pangan. Oleh karena itu, Bulog harus terus menjaga jumlah stok beras miliknya.

Pada tahun 2015 lalu, stok beras milik Perum Bulog tercatat total pengadaan sebanyak 1,85 juta ton. Pengamat pertanian Siswono Yudo Husodo mengatakan, masyarakat akan merasa aman kalau stok beras di gudang Perum.Bulog ada 2 juta ton setiap saat. Catatan dari Sekretariat Presiden sampai Oktober 2016, stok beras nasional di Bulog mencapai 1.980 juta ton. Hal itu menyebabkan pemerintah tidak memerlukan impor beras. Presiden menegaskan sampai akhir tahun 2016, tidak ada impor beras. Stok beras Bulog tersebut cukup sampai Mei 2017. Namun berdasarkan data BPS di Jakarta yang diolah dari sumber Ditjen Bea \& Cukai Kementerian Keuangan, pemerintah masih mengimpor beras tahun 2015 dan 2016. Artinya sejak 2000-2016 Indonesia mengimpor sebanyak 20,424 juta ton beras atau rata-rata 1,2 juta ton setiap tahun. Lihat grafik impor beras di bawah. Penyebab utamanya adalah produksi padi/beras yang turun; pertambahan penduduk sejak 2000; alih fungsi lahan tanaman pangan (padi), dan sebagainya. 


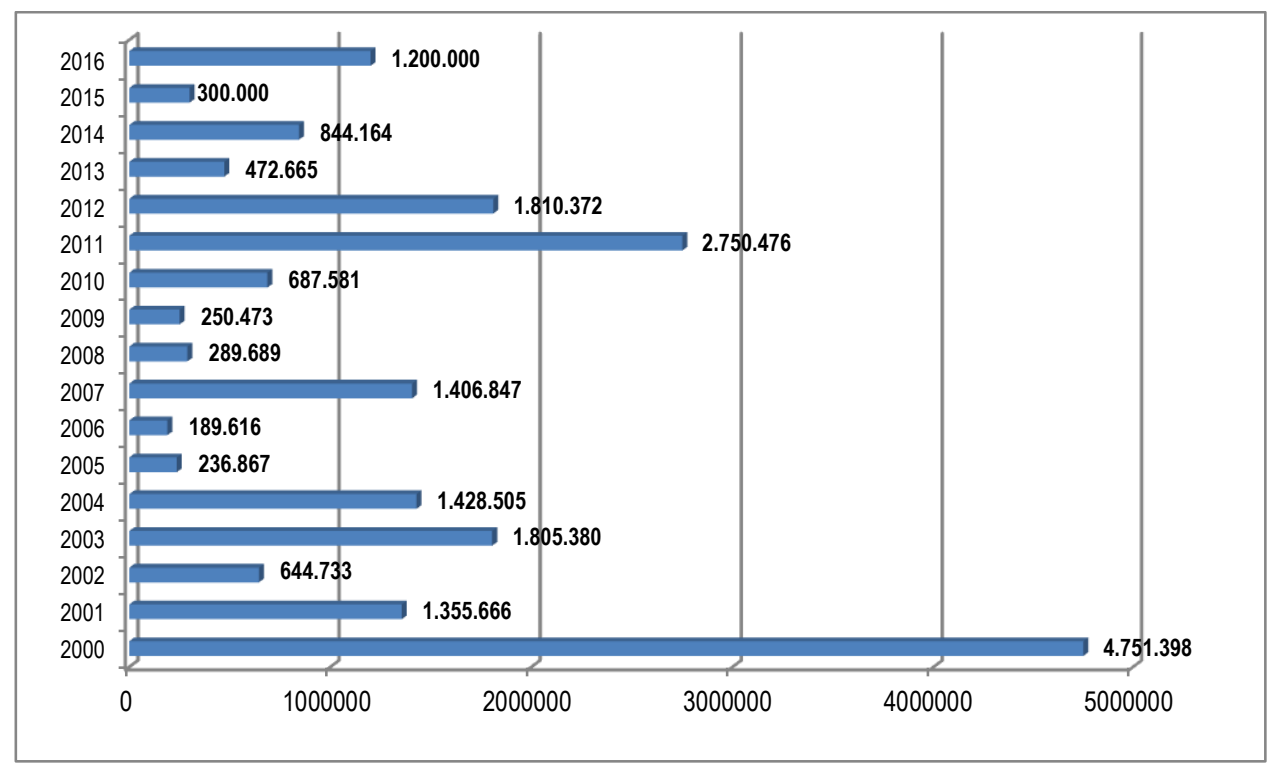

Gambar 4. Grafik Perkembangan Impor Beras Tahun 2000-2016 (Ton).

Sumber: Badan Pusat Statistik RI Jakarta dari Publikasi Statistik Indonesia.

Direktur Utama Perum Bulog menegaskan serapan Bulog sejak awal 2016 hingga saat ini sudah mencapai 870.000 -ton atau 25.000 ton per hari. Jika ditambah dengan stok yang dimiliki Bulog saat ini, kebutuhan beras pun dipastikan aman sampai Maret 2017. Dalam meningkatkan stok beras, Perum.Bulog juga telah merealisasikan impor beras medium sesuai yang ditugaskan pemerintah. Perum.Bulog mengimpor beras dari Thailand dan Vietnam awal Januari 2016 lalu mencapai 800.000-ton dan sisanya sebanyak 700.000-ton direalisasikan pada Februari dan Maret 2016. Selain impor, Perum Bulog terus berusaha meningkatkan penyerapan beras dari dalam negeri. Perum.Bulog pada musim panen di 2016 siap menyerap beras petani sebesar 2,6 juta ton. Untuk mencapai target penyerapan dalam negeri sebesar itu, Perum.Bulog pada April 2016 menyerap sekitar 750.000-ton beras, dan pada Mei 2016 menyerap 750.000-ton beras petani. Sehingga sampai Mei 2016, Bulog mampu menyerap 1,5 juta ton yang sebelumnya hanya 600.000 ton. Dirut Perum.Bulog mengakui dalam penyerapan beras di dalam negeri, Bulog memiliki sejumlah permasalahan di lapangan yakni; pertama, seperti perkembangan harga gabah atau beras yang masih cenderung di atas HPP. Kedua, waktu panen juga tidak serentak dan cenderung mundur. Sesuai Inpres No.5 Tahun 2015, Perum.Bulog hanya bisa membeli gabah kering panen (GKP) di tingkat petani sebesar Rp3.700/kg dan GKG di tingkat penggilingan sebesar Rp4.600/kg. Sementara untuk beras medium, Bulog hanya dapat membeli beras medium di gudang Bulog dengan harga maksimal Rp7.300/kg. Sayangnya, Bulog harus bersaing keras dengan pedagang yang berani membeli beras petani di atas harga Rp7.300/kg. Ketiga, kendala lainnya adalah space gudang di beberapa gudang Divre Bulog di sentra produksi beras masih minim sehingga stok beras di gudang masih tinggi dan infrastruktur pengolahan masih terbatas. Untuk mengatasi kendala tersebut, Perum.Bulog akan meningkatkan penyediaanspace gudang di Divre produsen dengan melakukan move out ke divre non produsen maupun melakukan sewa gudang swasta atau BUMN lain. Dengan berbagai upaya tersebut, Perum.Bulog akan berupaya menjaga stabilisasi harga beras sampai akhir Desember 2016.

\section{Sinergi Antara Bulog, Kementerian Pertanian, dan Kementerian Perdagangan}

Penguatan kelembagaan Bulog saat ini telah didukung oleh tiga regulasi baru yang dikeluarkan pemerintah yakni UU No.18 Tahun 2012 tentang Pangan, PP Nomor 13 Tahun 2016 
tentang Perusahaan Umum Bulog, serta Perpres Nomor 48 Tahun 2016. Walaupun saat ini juga ada kelembagaan yang mengurus pangan (sektor hulu) seperti Kementerian Pertanian tetapi 3 regulasi di atas merupakan payung hukum dan sebagai dasar kebijakan pangan termasuk upaya penguatan kelembagaan pangan guna memecahkan persoalan buruknya tata niaga pangan (hilir) selama ini yang menyebabkan gejolak harga pangan di pasar tidak terkendali.

Di sisi lain dalam hal urusan impor pangan (hilir) untuk menjaga ketahanan pangan nasional, institusi yang berkepentingan dan berwenang adalah Kementerian Perdagangan sebagai regulator. Perum.Bulog hanya sebatas pelaksana kebijakan pemerintah dalam hal ini Kementerian Perdagangan dan Kementerian Pertanian. Oleh karena itu sinergi ketiga kelembagaan urusan pangan di atas harus dikembangkan dan ditingkatkan terutama dalam koordinasinya. Sebab urusan pangan adalah urusan strategis negara yang menyangkut hajat hidup orang banyak dan lintas-sektor.

Tabel 3. Produksi Padi, Produksi Beras, dan Impor Beras Periode 2010-2016

\begin{tabular}{ccccc}
\hline \multirow{2}{*}{ Tahun } & Produksi Padi (ton) & $\begin{array}{c}\text { Produksi Beras } \\
\text { (ton)* }\end{array}$ & $\begin{array}{c}\text { Impor Beras } \\
\text { (ton) }\end{array}$ & $\begin{array}{c}\text { Rasio Impor } \\
\text { Beras }\end{array}$ \\
\cline { 4 - 5 } & & & Terhadap Produksi Beras (\%) \\
\hline 2010 & 66.469 .394 & 41.729 .486 & 687.581 & 1,6 \\
\hline 2011 & 65.756 .904 & 41.282 .184 & 2.750 .475 & 6,5 \\
\hline 2012 & 69.056 .126 & 43.353 .436 & 1.810 .372 & 4,2 \\
\hline 2013 & 61.969 .374 & 38.904 .373 & 472.665 & 1,2 \\
\hline 2014 & 70.607 .231 & 44.327 .220 & 844.164 & 1,9 \\
\hline 2015 & 75.360 .000 & 47.476 .800 & 300.000 & 0,2 \\
\hline $\left.2016^{* *}\right)$ & 79.141 .000 & 49.067 .420 & 1.200 .000 & 2,4 \\
\hline
\end{tabular}

Keterangan $\quad: *$ ) Produksi beras rata-rata sebesar $62-63 \%$ dari produksi padi.

**) Proyeksi (Angka Ramalan).

Sumber: Kebijakan impor, cadangan pangan, stabilisasi harga dan ketahanan pangan nasional berkemandirian oleh Erwidodo, dalam http://www.litbang.pertanian.go.id/buku/swasembada /BAB-III-3.pdf

Berdasarkan analisis terhadap eskalasi harga pangan pokok seperti dijelaskan pada di atas, maka penguatan kelembagaan stabilitas harga pangan (pokok) perlu direalisasikan segera di samping tugas penyediaan (supply). Penguatan atau aransemen kelembagaan pangan yang dimaksud di sini adalah difokuskan pada Perum.Bulog yang dapat diartikan secara struktural sebagai perwujudan dari ketentuan UU No.18 Tahun 2012 tentang Pangan. Walaupun tidak secara tegas diatur dan disebutkan kelembagaan pangan dalam UU Pangan, namun pada Pasal 126-129 UU No.18 Tahun 2012 telah diamanatkan secara eksplisit kepada pemerintah untuk membentuk lembaga pemerintah yang menangani bidang pangan yang berada di bawah dan bertanggung jawab kepada Presiden. Kelembagaan dimaksud dalam hal ini adalah Perum.Bulog. Lembaga pangan ini diharapkan mampu melaksanakan tugas pemerintahan di bidang urusan pangan saat ini dan ke depan sesuai undang-undang.

Kelembagaan tentang stabilisasi harga pangan secara kultural atau secara sistem nilai, sebenarnya dapat dilaksanakan langsung oleh pemerintah melalui Kementerian Pertanian dan Kementerian Perdagangan apabila pemerintah memiliki kewibawaan kebijakan di bidang 
pangan. Terdapat lima hal penting yang perlu diketahui atau dipahami pemerintah dalam upaya penguatan kelembagaan pangan ke depan, antara lain: Pertama, penemuan harga (price discovery) melalui negosiasi formal dan informal oleh pelaku ekonomi atau perusahaan; Kedua, perdagangan biasa, pasar lelang, baik secara fisik, maupun secara elektronik; Ketiga, formula pembentukan harga yang fair; Keempat, kesepakatan harga pada kelompok produsen, distributor, dan asosiasi pedagang yang melibatkan pemerintah; Kelima, keputusan khusus oleh lembaga pemerintah karena pertimbangan tertentu.

Implementasi kelembagaan untuk stabilitas harga pangan misalnya, memerlukan adaptasi terhadap sistem dan kebijakan non-pangan yang berlaku di Indonesia. Sebab kebijakan non-pangan juga turut menentukan keberhasilan operasional kelembagaan pangan, seperti Perum Bulog, Kementerian Pertanian, dan Kementerian Perdagangan yang secara langsung mengurusi sektor pangan. Perum.Bulog memang bukanlah suatu lembaga pemerintah tetapi dalam menjalankan tugasnya Perum.Bulog telah memiliki "power" dengan diberi kewenangan dan diskresi untuk mengurusi 9 bahan kebutuhan pokok sebagaimana diatur dalam PP No.13 Tahun 2016 dan Perpres No.48 Tahun 2016. Perpres ini diterbitkan untuk menjalankan Pasal 3 PP Nomor 13 Tahun 2016 tentang Perusahaan Umum Bulog. PP No.13 Tahun 2016 adalah menggantikan PP No.7 Tahun 2003.

Kewajiban Perum.Bulog dalam rangka stabilitas harga pangan pokok hingga di tingkat konsumen dan produsen ini sebenarnya positif. Namun, tidak mudah dalam implementasinya. Pertama, realitas di lapangan menunjukan bahwa Bulog dan BUMN pangan lainnya bukanlah pemain utama di pasar. Berdasarkan informasi dari Komisi Pengawas Persaingan Usaha (KPPU) Bulog hanya menguasai 20-25\% pangsa pasar beras di Indonesia. Sebaliknya, pengusaha beras menguasai sekitar 75-80\% pangsa pasar. Kondisi ini tentunya menempatkan Bulog pada posisi yang kurang ideal dalam hal stabilisasi harga. Kedua, mata rantai bisnis bahan pangan cukup panjang dan banyak melibatkan pemain. Berdasarkan survei BPS tahun 2015, distribusi perdagangan beras di Indonesia melibatkan produsen (importir pangan dan petani), distributor, pedagang pengumpul, sub distributor, agen, sub agen, pedagang grosir, pedagang eceran, supermarket baru kemudian beras sampai ke tangan konsumen (rumah tangga dan non rumah tangga). Panjangnya rantai distribusi komoditas pangan seperti beras membuat jangkauan pengawasan Bulog menjadi terbatas. Hal ini juga salah satu penyebab utama mahalnya harga pangan pokok seperti beras, daging sapi, daging ayam, dan gula pasir di pasar. Dengan kapasitas Bulog yang terbatas, akan sulit bagi Bulog dapat menjamin harga hingga di tingkat konsumen sesuai kehendak pemerintah apabila Bulog belum menjadi market leader. Terlalu berat bila Bulog dibebani kewajiban untuk memastikan kestabilan harga pangan sampai di tingkat konsumen apabila Bulog tidak diperkuat terutama dari sisi finansial. Implikasinya, bila harga pangan di tingkat konsumen melonjak akibat permainan harga yang dilakukan pihak di luar Bulog, maka Bulog berpotensi mempunyai berbagai risiko (risiko finansial, operasional, hukum, dan risiko reputasi). Kita menyaksikan, misalnya, Bulog terpaksa harus berurusan dengan kasus-kasus hukum yang tidak terkait langsung dengan Bulog.

Faktanya Bulog akhir-akhir ini memiliki stok beras relatif sedikit karena antara lain tidak mampu bersaing dengan pedagang pengumpul atau pengusaha penggilingan padi/gabah. Hingga November 2015 misalnya volume beras di gudang Bulog 1,7 juta ton terdiri dari 1,1 juta ton beras medium dan 0,6 juta ton beras kualitas premium. Padahal idealnya Bulog dapat memiliki stok sampai 4 juta ton setiap tahun. Dampaknya harga beras dapat naik. Strategi yang dilakukan oleh pengusaha/pedagang pengumpul ke petani adalah denga memberi 
pinjaman kepada petani pada saat sebelum panen raya untuk membeli saran produksi. Konsekuensinya hasil panen padi petani tersebut dijual ke pengusaha penggilingan/pedagang pengumpul.

Dengan melihat realitas di atas bahwa pengamanan harga pangan sampai ke tingkat konsumen seyogyanya tidak menjadi tanggung jawab Bulog semata. Tanggung jawab Bulog (dan BUMN pangan lainnya) perlu disesuaikan dengan jangkauan kewenangannya. Dalam hal ini, mungkin ada baiknya bila model tanggung jawab menjaga kestabilan harga pupuk (bersubsidi) dapat diterapkan pada penanganan harga pangan. Pada komoditas pupuk misalnya, tanggung jawab produsen pupuk untuk menjaga kestabilan harga hanya sampai distributor. Selanjutnya, harga di tingkat pengecer menjadi tanggung jawab distributor. Bila terjadi penyimpangan harga oleh pengecer, distributor yang bertanggung jawab. Dengan pola seperti ini, produsen pupuk bisa fokus dalam menjaga produksi pupuknya. Dan bila pola ini diterapkan pada Bulog (dan BUMN pangan lainnya), Bulog juga bisa lebih fokus pada isu-isu yang lebih strategis dalam mewujudkan ketahanan pangan secara nasional sekaligus meningkatkan kapasitas usahanya. Gagasan Kementerian BUMN yang akan membentuk induk perusahaan (holding) BUMN sektor pangan baik yang bergerak di sektor produksi maupun perdagangan (distribusi) adalah baik. Bertindak sebagai holding company BUMN adalah Perum.Bulog yang akan membawahi PT. Sang Hyang Seri, PT. Pertani, PT. Berdikari, PT. Perikanan Nusantara, PT. Perusahaan Perdagangan Indonesia, dan PT. Bhanda Ghara Reksa. Di lihat dari sisi korporasi, konsep holding BUMN ini positif bagi peningkatan kapabilitas BUMN pangan. Namun, yang perlu dicatat bahwa pembentukan holding company ini merupakan salah satu dari keseluruhan rangkaian upaya mewujudkan ketahanan pangan. Di luar itu, konsep holding BUMN pangan ini juga perlu disinkronkan dengan keberadaan kelembagaan pangan yang seharusnya dibentuk sesuai dengan mandat dari UU No. 18 Tahun 2012.

Selain pembenahan secara korporasi, pembenahan kelembagaan pangan lainnya juga perlu dilakukan. Untuk mendukung ketahanan pangan dan stabilisasi harga, diperlukan perbaikan infrastruktur dan tata niaga pangan. Pembenahan kelembagaan basis produksi (Kementan) dan tata niaga pangan (Kemendag) saat ini dirasakan masih kurang memadai dan kurang koordinasi. Selain itu, rantai tata niaga beberapa komoditas pangan di luar beras masih belum efektif. Masih banyak hal yang memang perlu dibenahi dalam upaya untuk mewujudkan ketahanan pangan dan stabilitas harga pangan. Perlu pembenahan secara konsisten terhadap seluruh aspek terkait dengan upaya mewujudkan ketahanan pangan dan stabilitas harga, baik dari sisi kapabilitas korporasi, infrastruktur, regulasi hulu dan hilir, dan kelembagaan pangan akan dapat mempercepat upaya tersebut.

Dari sisi hulu, Kementerian Pertanian harus dapat menjamin peningkatan produksi pangan pokok guna memenuhi kebutuhan pasar. Apabila produksi pangan turun maka pasokan akan berkurang sehingga pada akhirnya akan meningkatkan harga. Implikasinya akan mendorong untuk dilakukannya impor guna memenuhi kekurangan kebutuhan pasar seperti yang terjadi pada sebagian besar komoditas pangan seperti daging sapi, Gula Kristal Putih, kedelai, dan lain-lain. Konsep ketahanan pangan memang tidak mempersoalkan impor, tetapi naiknya harga impor pangan justru akan mengancam ketahanan pangan karena persoalan mahalnya harga pangan impor di pasar domestik. Dalam hal impor pangan, regulator adalah Kemendag. Oleh sebab itu Kemendag perlu berkoordinasi dengan Kementan dan Bulog mengenai kapan dilakukan impor dan komoditas apa yang perlu diimpor. Ketersediaan pangan sama pentingnya dengan menjaga stabilitas harga pangan. Tiga pilar pangan di atas tetap menjadi instrumen 
dalam memformulasikan regulasi di sektor pangan baik di sisi hulu maupun hilir.

Menurut Lokot Zein Nasution, apabila Bulog berperan sebagai penyeimbang dan pelaksana impor untuk pengontrol harga pangan maka pengembalian peran dan fungsi Bulog tersebut tidak dapat dilakukan jika statusnya sebagai BUMN karena memiliki dwifungsi sebagai tugas publik dan fungsi bisnis. Oleh karena itu perlu mereformasi status Bulog menjadi semacam badan layan umum (BLU) yang dibentuk untuk memberikan pelayan kepada publik berupa penyediaan barang dan jasa yang dijual tanpa untung tetapi tetap memegang prinsip kinerja organisasi dan produktivitas.

Pandangan Nasution di atas tidak sepenuhnya benar karena bukan status Bulog yang menjadi persoalan dalam pencapaian ketahanan pangan, tetapi bagaimana sinergi dan koordinasi yang baik antar-kelembagaan pangan yang ada baik dari sisi hulu maupun sisi hilir. Apabila di sisi hulu (supply) terganggu karena produksi pangan yang berkurang maka hal ini menjadi tanggungjawab Kementan karena kebutuhan pasar tidak terpenuhi dari dalam negeri sehingga impor harus dilakukan guna menjaga ketahanan pangan. Tetapi dalam implementasi kebijakan impor, maka Bulog harus diberi kewenangan penuh dan menjadi pelaksana tunggal impor sehingga akan tercipta harga pangan yang stabil di pasar. Bulog sebagai pelaksana tunggal impor memiliki power untuk penetrasi ke pasar domesik yang kekurangan supply sebagaimana yang pernah dilakukan masa Orde Baru terhadap 9 bahan pokok. Padahal status Bulog belum menjadi badan usaha dan tidak dapat disebut sebagai badan layanan umum. Sampai kapan pun apabila pemerintah tidak bisa mengantisipasi dan mengatasi lonjakan kebutuhan pangan dalam negeri, maka harga pangan akan cepat meningkat yang pada akhirnya dapat menyebabkan inflasi. Ketahanan pangan-pun menjadi terancam tidak terkecuali terhadap komoditas beras.

\section{SIMPULAN}

Perubahan status, tugas, dan wewenang lembaga pangan yang sering terjadi sejak kemerdekaan sampai saat ini merupakan salah satu penyebab utama upaya ketahanan pangan sering tidak tercapai. Kuatnya rezim pemerintahan masa Orde Baru dengan pemberian kewenangan penuh kepada Bulog serta dukungan kebijakan pertanian dan perdagangan, telah membuahkan relatif hasil stabilnya harga pangan sejak 1983-1997 karena sistim dan tata niaga pangan terjaga dengan baik serta koordinasi antarlembaga pangan yang juga baik.

Pergantian rezim pemerintahan paska Orde Baru pencapaian ketahanan pangan tidak semakin baik bahkan menurun antara lain disebabkan oleh perubahan tugas dan wewenang Bulog terutama adanya "intervensi" dari IMF dan Bank Dunia yang membatasi wewenang dan tanggungjawab Bulog hanya sebagai stabilisator harga pangan beras saja padahal pemerintah telah melahirkan UU Nomor 7 Tahun 1996 tentang pangan yang intinya bahwa pemeirntah bertanggungjawab menjaga ketahanan pangan.

Sejak 2003 dengan perubahan status Bulog dari lembaga pemerintah non-departemen menjadi BUMN berbentuk perusahaan umum, Perum.Bulog masih dihadapkan pada dilemma tugas dan fungsi yakni di satu sisi menjalankan tugas publik (public sevice obligation) yang ditugaskan negara, tetapi di sisi lain Perum.Bulog juga dituntut untuk mengejar keuntungan (fungsi bisnis). Dalam realita paska Perum, Bulog masih tidak mampu untuk meredam gejolak harga pangan di luar control harga beras, karena antara lain kurangnya koordinasi dan tidak adanya sinergi antara Bulog, Kementan, dan Kemendag dalam urusan pangan pokok. Hal ini juga menyebabkan masih panjangnya mata rantai tata niaga pangan sehingga mengancam stabilitas harga beberapa komoditas pangan pokok. 
Status Bulog sebagai Perum merubah kedudukan/tata kelola dari lembaga yang bertanggungjawab kepada presiden menjadi perusahaan publik di bawah Menteri Negara BUMN. Konsekuensi logisnya adalah Perum diperlakukan sama dengan perusahaan bisnis swasta. prinsip akuntasi umum berlaku. Oleh karena itu, prinsip efisiensi dan manajemen usaha yang baik seperti good corporate governance diperlukan agar Perum.Bulog dapat eksis dan bersaing dalam usaha komoditas pangan. Perum perlu dikembangkan kearah yang lebih luas cakupannya yakni masuk dalam perdagangan bahan pangan secara komersial. Dengan demikian, Bulog mampu mengendalikan harga pangan bukan dengan menimbun atau menjual cadangan bahan pangan (beras), dengan dinamisasi dan normalisasi perdagangan.

Sedangkan pemilihan bentuk lembaga pangan haruslah dari perspektif yang lebih luas yaitu optimasi investasi negara dan ketahanan pangan nasional. Dengan perspektif ini, pilihan tidak dapat ditetapkan dengan melihat unjuk kerja lembaga yang sudah ada, tetapi lebih pada kebutuhan terhadap lembaga tersebut. Perum Bulog perlu melakukan self-assessment dalam perspektif kepentingan nasional. Pilihan akhir ditentukan oleh kesiapan lembaga yang sudah ada, serta peran dan fungsi yang harus dikerjakan.

\section{DAFTAR PUSTAKA}

Kementerian Pertanian RI, (2015), Kinerja Satu Tahun Kementerian Pertanian: Oktober 2014-Oktober 2015, Penerbit Kementerian Pertanian RI Jakarta.

Pasandaran, Effendi, dkk, (2015), Memperkuat Kemampuan Swasembada Pangan, Penerbit IAARD Press, Balitbang Kementan RI, Jakarta, hal.270.

Prawiro, Radius, (2004), Pergulatan Indonesia Membangun Ekonomi, Penerbit PT.Primamedia Pustaka, Jakarta.
Suksmantri, Eko.,dkk, (2012), Bulog Dalam Bingkai Ketahanan Pangan, Penerbit CV.Padma Publisher,Jakarta.

Bantacut, Tajuddin, (2014), Agenda Pembangunan Pertanian dan Ketahanan Pangan 2014-2019 (The Agenda of Agricultural Development and Food Security 2014-2019), Jurnal Pangan, Vol.23, No.3 Tahun 2014, Penerbit Pusat Riset dan Perencanaan Strategis

Perum.Bulog, Jakarta, hal.285. , (2008), Menjadikan Bulog Lembaga Pangan yang Handal, Jurnal Pangan, Vo.17 No.1 Tahun 2008, hal. 77.

Hasibuan, Ahmad IR.Surya, (2015), Kebijakan Pangan Pasca Ratifikasi Agreement on Agriculture (AoA) WTO, Jurnal Politik dan Masalah Pembangunan, Vol.11, No.01 Tahun 2015, Penerbit Universitas Nasional (Unas),Jakarta, Hal.1638-1639.

Nasution, Lokot Zein, (2016), Reposisi peran dan fungsi Bulog dalam tata niaga pangan, Jurnal Kajian, Vol.21 No.1 Maret 2016, Penerbit Pusat Penelitian BK DPR RI, Jakarta, hal. 68-69.

Suswono, dkk, (2009), Strategi Peningkatan Daya Saing Perum Bulog, Jurnal Manajemen dan Agribisnis, Vol.6 No.2 Oktober 2009, Penerbit Institut Pertanian Bogor (IPB), hal.94.

\section{Artikel Online}

Alur Pengadaan Beras/gabah oleh Perum.Bulog dari Petani, dalam www.bulog.co.id.

Bulog bersaing dengan pedagang beli beras,dalam http://agroindonesia.co.id/, diakses 14 Desember 2016. Bulog Kehilangan Momentum dalam Pengadaan Beras, dalam http:// print.kompas.com /baca/ekonomi/sektorriil/2015/08/27/Bulog-KehilanganMomentum-dalam-Pengadaan-Beras, diakses 13 Desember 2016.

Harian Kontan, 3 Maret 2015. 
Jokowi Pastikan Stok Pangan Nasional Aman hingga Mei 2017, dalam http://nasional.kompas.com., diakses 13 Desember 2016.

National Food Authority of Philippine, dalam http://www.nfa.gov.ph/buying-sellingprice., diakses 15 Desember 2016.

Pemerintah Akui Stabilitas Harga Pangan Belum Tercapai, dalam http://www.republika.co.id/berita/ekon omi/makro/16/10/19/ofaji3382-

pemerintah-akui- stabilitas-hargapangan-belum-tercapai, diakses 8 Desember 2016

Public Warehouse Organization (PWO)'s Quality Rice from Thailand. dalam http://www.thaitradeusa.com/home/, diakses 15 Desember 2016.

PadiBeras National Berhad (Bernas) Malaysia, dalam http://www.bernas.com.my/, diakses 15 Desember 2016.

Peran Bulog Dalam Kebijakan Perberasan Nasional oleh Agus Saifullah, dalam http://bulog.co.id/data/, diakses 16 Desember 2016.

Rencana Strategis Kementerian Pertanian 20142019, dalam http://www.pertanian.go.id/ file/RENST RA_2015-2019.pdf, diakses 20 Desember 2016.

Tiga tujuan utama kebijakan pangan menurut Jokowi, dalam http://www.rappler.com/indonesia/120 494-kebijakan-pangan-pemerintahjokowi， diakses 9 Desember 2016

Tinjauan yuridis kedudukan dan fungsi Bulog pasca dikeluarkannya Keppres Nomor 166 Tahun 2000 dalam rangka mewujudkan kedaulatan pangan, oleh Erico Leonard Hutauruk, FHUniversitas Atma Jaya Yogyakarta, 2014, dalam http://ejournal.uajy.ac.id/5860/1/JURNAL.pdf, diakses 16 Desember 2016.
UU Nomor 7 Tahun 1996 tentang Pangan.

UU Nomor 18 Tahun 2012 tentang Pangan.

UU Nomor 19 Tahun 2003 tentang BUMN.

PP No. 7 Tahun 1958.

PP No. 47 Tahun 1958.

PP No. 7 Tahun 2003 tentang Bulog.

PP No. 17 Tahun 2015 tentang Ketahanan pangan dan gizi.

PP No. 13 Tahun 2016 tentang Bulog.

Perpres No. 48 Tahun 2016 tentang Penugasan Kepada Bulog Dalam Rangka Ketahanan Pangan Nasional

Keppres No. 69 Tahun 1967.

Keputusan Presidium Kabinet No. 114/U/Kep. /5/1967.

Keppres No. 261 Tahun 1967 tentang Pembemnetukan Panitia Pengadaan Pangan Rakyat.

Keppres No.11 Tahun 1969 tentang Struktur Organisasi, Tugas dan Fungsi Bulog.

Keppres No. 39 Tahun 1978 tentang Bulog.

Keppres No.103 Tahun 1993 tentang Bulog.

Keppres No. 50 Tahun 1995.

Keppres No. 45 Tahun 1997.

Keppres No.19 Tahun 1998.

Keppres No. 29 Tahun 2000.

Keppres No. 166 Tahun 2000.

Keppres No. 03 Tahun 2002.

Inpres No. 7 Tahun 1979 tentang Harga pembelian gabah dan beras oleh Bulog.

Inpres No. 22 Tahun 1979 tentang Perubahan Inpres No.7/1979.

Inpres No. 3 Tahun 2007 tentang Kebijakan Perberasan.

Inpres No.3 Tahun 2012 tentang Kebijakan Pengadaan Gabah/Beras dan Penyaluran Beras oleh Pemerintah

Inpres No. 5 Tahun 2015.

\section{Peraturan Perundang-undangan}

